\title{
LAW, ENVIRONMENT, AND VISION
}

\author{
Douglas A. Kysar"
}

\section{INTRODUCTION}

[A]nalytic effort is of necessity preceded by a preanalytic cognitive act that supplies the raw material for the analytic effort .... [T] [Tis preanalytic cognitive act will be called Vision. ${ }^{1}$

Environmental law rests uncomfortably between competing visions. Once driven by essentially "moral, cultural, aesthetic, and political purposes," the environmental regulatory agenda now seems, like other aspects of the emerging "cost-benefit state," Although the environmental law framework established during the predominant ethical environmentalism of the 1970 s remains largely intact, ${ }^{4}$ commentators today agree that this framework represents "a failing paradigm." The future of environmental regulation, instead, lies in such efficiency-oriented instruments as tradable permits, corrective taxes, disclosure schemes, and other tools designed to replicate the conditions of a wellfunctioning market. ${ }^{6}$ Indeed, scholars have labeled tradable permits "the

\footnotetext{
* Assistant Professor of Law, Cornell Law School. B.A., 1995, Indiana University. J.D., 1998, Harvard University. For helpful comments on earlier drafts, I thank Gregory Alexander, Steven Clymer, George Hay, Lisa Heinzerling, Jeffrey Rachlinski, Mark Sagoff, James Salzman, Steven Shiffrin, David Spence, and participants of the Stanford/Yale Junior Faculty Forum, the Environmental Research Workshop at the Georgetown University Law Center, the Public Policy Research/Law and the Behavioral Sciences Programs Workshop at the University of California, San Diego, and a faculty workshop at Cornell Law School. I especially thank Vicki Been and Buzz Thompson for their generosity in providIng extensive comments and discussing at length the issues addressed herein. All misjudgments, errors, and omissions are my own.

1 JOSEPH A. SCHUMPETER, HISTORY OF ECONOMIC ANALYSIS 41 (1954)

2 MARK SAGoff, THE ECONOMY OF THE EARTH 6 (1988)

3 See Cass R. Sunsten, The Cost-Benefit State, at ix (2002) ("Gradually, and in fits and starts, American government is becoming a cost-benefit state.").

${ }^{4}$ See Richard B. Stewart, A New Generation of Environmental Regulation?, 29 CAP. U. L. REV. 21, 25 (2001).

${ }^{5}$ Richard B. Stewart, United States Environmental Regulation: A Failing Paradigm, 15 J.L. \& COM. 585 (1996).

${ }^{6}$ See, e.g., Jonathan Baert Wiener, Global Environmental Regulation: Instrument Choice in Legal Context, 108 YALE L.J. 677, 682 (1999) (noting consensus among analysts "that incentive-based instruments such as taxes and tradeable allowances should generally be chosen over technology requirements and fixed emissions standards because the incentive-based instruments are typically far more costeffective and innovation-generating than their alternatives").
} 
most fashionable innovation in environmental policy today,"7 promising not only to achieve regulatory goals with less cost than traditional commandand-control techniques, but also promising to inspire reasoned public deliberation regarding such weighty issues as the very type of environment in which we desire to live. ${ }^{8}$

As Lisa Heinzerling argues, however, the "republican moment" promised by tradable permit schemes has proven stubbornly elusive, at least if experience with the sulfur dioxide trading program created by the 1990 Clean Air Act Amendments is indicative. ${ }^{10}$ According to proponents of tradable permit schemes, enacting such legislation forces explicit discussion by lawmakers and their constituents regarding the goals of environmental protection due to the fact that such schemes require the government to establish an aggregate limit to the amount of pollution emitted or resources used in a given time period. " Yet, as Heinzerling's study of the legislative history of the Clean Air Act Amendments reveals, no such public discussion took place with regard to the sulfur dioxide trading program. ${ }^{12}$ Instead, Congress devoted nearly all of its attention to allocating valuable property rights created under the scheme among clamoring interest groups. ${ }^{13}$ In other words, Congress fixated on dividing up the pork.

This Article argues that the failure of existing environmental trading programs to inspire serious democratic deliberation about environmental goals is caused in no small part by a fundamental conceptual flaw in our background assumptions about the natural world and its relation to our economic activity. Specifically, because mainstream economic accounts generally fail to recognize absolute limits imposed by nature on the ability of humans to appropriate and utilize natural resources, they also fail to provide an adequate conceptual basis on which to make the political judgments re-

${ }^{7}$ Lisa Heinzerling, Selling Pollution, Forcing Democracy, 14 STAN. ENVTL. L.J. 300, 301 (1995); see also Carol M. Rose, Expanding the Choices for the Global Commons: Comparing Newfangled Tradable Allowance Schemes to Old-Fashioned Common Property Regimes, 10 DUKE ENVTL. L. \& POL'Y F. 45, 51-52 (1999) (noting that tradable permits are "a matter of considerable interest in global environmentalism").

8 See Bruce A. Ackerman \& Richard B. Stewart, Reforming Environmental Law, 37 STAN. L. REV. 1333, 1341-51 (1985); Bruce A. Ackerman \& Richard B. Stewart, Reforming Environmental Law: The Democratic Case for Market Incentives, 13 ColuM. J. ENvTL. L. 171, 178-88 (1988); Richard B. Stewart, Madison's Nightmare, 57 U. CHI. L. REV. 335, 353-54 (1990); Richard B. Stewart, Controlling Environmental Risks Through Economic Incentives, 13 CoLUM. J. ENVTL. L. 153, 158-62 (1988); Cass R. Sunstein, Administrative Substance, 1991 DUKE L.J. 607, 634-40 (1991); Cass R. Sunstein, Democratizing America Through Law, 25 SUFFOLK U. L. REV. 949, 964-66 (1991).

9 James Gray Pope, Republican Moments: The Role of Direct Popular Power in the American Constitutional Order, 139 U. PA. L. REV. 287 (1990).

${ }^{10}$ See Heinzerling, supra note 7 . The trading program is codified at 42 U.S.C. $\$ \S 7651-76510$ (2000)

11 See sources cited supra note 8.

12 Heinzerling, supra note 7, at 319-28.

13 See id. at 328-32. 
quired by tradable permit schemes. Just as cost-benefit analysis seems incoherent under the moral absolutism of 1970s-era environmental statutes, ${ }^{14}$ setting aggregate limits to annual sulfur dioxide emissions appears nonsensical, or at least not urgent, within a theoretical model that recognizes no ultimate constraints to economic growth.

Fortunately, an alternative vision exists: ecological economics. During the shift to efficiency-oriented environmental regulation, legal scholars have paid little attention to this emerging academic field that seeks to bring multidisciplinary rigor to the study of nature's role within human economic production..$^{15}$ By fusing insights from ecology, population biology, and physics with the theoretical framework of economics, ecological economists attempt to provide a more nuanced understanding of humanecosystem interactions than those offered independently by either economists or conservationists. Significantly, ecological economists rely on a preanalytic vision of human activity that is presumed to be bounded by natural constraints. This vision, or worldview, provides a simple yet surprisingly radical departure from mainstream economic thought. ${ }^{16}$ It also provides the basis for an alternative conception of the goals of collective governance, one that brings much-needed coherence to environmental decisionmaking within the paradigm of market-based regulation.

Part I reviews in more detail the case for adopting ecological economics as a theoretical model for legal analysis. Part II then examines a series of specific areas of law and regulation in which ecological economic insights can inform the choice of rules or polices. One goal of this Article is to demonstrate that ecological economics can be, and to a large extent already has been, operationalized through concrete regulatory proposals. Indeed, many of the policy tools reviewed in Part II will be familiar to those

14 See infra text accompanying notes $129-34$

15 See AN InTroduction to ECOlogical Economics 5 (Robert Costanza et al. eds., 1997) ("[Ecological economics] is a return to a point when economics and other sciences were integrated rather than academically isolated as they are now."). The legal academy has not completely ignored the development of ecological economics. Jeff Lewin provided an early exception in an essay exploring the implications of the field for law and economics. See Jeff L. Lewin, Toward a New Ecological Law \& Economics, in LAW AND ECONOMICS: NEW AND CRITICAL PERSPECTIVES 249 (Robin Paul Malloy \& Christopher K. Braun eds., 1995). More recently, James Salzman, Barton Thompson, Jr., and others have devoted considerable energy to the project of acknowledging and analyzing the concept of ecosystem services, a notion that features prominently in the ecological economic literature. See James Salzman, Valuing Ecosystem Services, 24 EcologY L.Q. 887, 893 (1997); James Salzman et. al., Protecting Ecosystem Services: Science, Economics, and Law, 20 STAN. ENVTL. L. REV. 309, 327 (2001) (Introducing symposium issue devoted to the topic of "ecosystem services"); Barton $\mathrm{H}$. Thompson, $\mathrm{Jr}$, Markets for Nature, 25 WM. \& MARY ENVTL. L. \& POL'Y REV. 261 (2000). Additionally, in an earlier work, 1 have argued for the adoption of ecological economics as a general macroeconomic model for legal analysis. See Douglas A. Kysar, Sustainability, Distribution, and the Macroeconomic Analysis of Law, 43 B.C. L. REV. 1 (2001),

16 See Herman E. Daly, Ecological Economics and the ECology of Economics 50 (1999) (noting that when one adopts the ecological economic vision, "[e]conomic logic stays the same, but the perceived pattem of scarcity changes radically and policies must be changed radically"). 
conversant in the environmental law literature. The additional contribution that this Article seeks to make is to reexamine those proposals in light of the integrative vision provided by ecological economics. As a consequence, the tenor of the following discussion may at times seem highly, perhaps even excessively, theoretical. This is not an accident. The central premise of this Article is that environmental law does not suffer from a lack of well-designed, well-studied policy tools to achieve its goals, but rather from a lack of urgency among policymakers and the public concerning the necessity to achieve those goals. Such urgency simply does not follow from a preanalytic worldview in which nature is assumed to be boundless.

\section{AN OVERVIEW OF ECOLOGICAL ECONOMICS}

In early 2001, Daimler Chrysler A.G. began marketing a four-wheel drive vehicle so massive in dimension and weight that it must comply with federal regulations applicable to eighteen-wheel trucks. ${ }^{17}$ The vehicle, called The Unimog by Daimler, is three feet taller than the tallest sportutility vehicle, nearly two feet wider than a typical car, and one foot longer than the Ford Excursion, the longest sport utility previously available on the consumer market. It weighs 12,500 pounds, a heft equal to "more than two Chevrolet Suburban sport utility vehicles or four Toyota Camry sedans."18 The Unimog averages only ten miles per gallon of diesel fuel and is restricted from traveling on some roads and bridges because it exceeds local weight and height limits. Nevertheless, Daimler offers the vehicle to affluent suburbanites, whether they are off-road enthusiasts or simply "moms [who] want to take it to the grocery store."19

The Unimog provides an apt symbol of the debate between ecological economists and their more conventional counterparts. Most economists today would recognize that the Unimog produces a variety of negative externality problems. Its poor fuel efficiency, to give just one example, highlights the contribution of petroleum-powered vehicles to global climate change through the emission of greenhouse gases. ${ }^{20}$ Thus, in order to ensure that the Unimog represents a welfare-enhancing use of society's resources, prevailing economic theory would require that it (and all other vehicles) bear a tax representing the uncounted costs of pollution caused by the vehicle's production and use. ${ }^{21}$

Beyond using Pigouvian taxes to address pollution externalities, how-

\footnotetext{
17 Keith Bradsher, Daimler To Offer a Monster S.U.V, N.Y. TIMES, Feb. 21, 2001, at C1.

${ }^{18}$ Id. at $\mathrm{Cl}, \mathrm{C} 4$.

19 Id. (quoting Bruce Bames, marketing manager for the Unimog).

${ }^{20}$ See Jeffrey J. Rachlinski, The Psychology of Global Climate Change, 2000 U. ILL. L. REV. 299, $300(2000)$.

${ }^{21}$ See infra note 61. Alternatively, one might attempt to correct for the externality by creating enforceable property rights in the atmosphere, such that private owners would have an incentive to bargain for poliution reductions from those who threaten the stability of their resource. See infra note 62 .
} 
ever, most conventional economists would not be concerned whether petroleum-based plastics, metals, and other nonrenewable resources required to produce the six-and-a-half ton behemoth should be preserved by society for future applications. Nor would they be particularly concerned that the Unimog's marketing materials reflect a culture of competitive consumption that may waste scarce resources in a sort of S.U.V. "arms race."22 Such considerations would not figure prominently in the conventional economist's analysis of the Unimog because, so long as the price of the vehicle internalizes tangible external costs, one would have little reason to believe that its natural capital components could be allocated to other, more beneficial uses, either currently or in the future.

Ecological economists, on the other hand, believe that those excluded considerations raise vital issues of intra- and intergenerational resource distribution. A pollution tax on the Unimog would be a good start, according to the ecological economists, but it hardly would answer the more fundamental question of how to ensure that humanity equitably distributes its finite endowment of natural capital within and across generations. Indeed, ecological economists might well view the Unimog as emblematic of a wasteful society that forsakes its obligations to the future in exchange for a present, but ephemeral natural resource binge. Although the makers of the Unimog assure customers that "[w]anting to conquer the great outdoors is simply not a good reason to give up . . . air conditioning," 23 ecological economists would argue that there are other, more theoretically sound reasons to forego both.

This Part provides a brief overview of the conceptual disagreement between conventional and ecological economists-a debate that raises farreaching questions concerning sustainability, distribution, and the macroeconomic analysis of law. ${ }^{24}$ Readers should be warned both that the discussion focuses on these two theoretical paradigms at a highly abstract level and that the actual state of contemporary environmental regulation bears little relationship to either paradigm. ${ }^{25}$ This theoretical focus serves an important purpose, however, because it is arguably at the level of theory that more intellectual development is needed. As will be seen in Part II, both mainstream and ecological economists have devoted considerable insight

22 The Unimog's sales brochure opens with the following challenge:

There are a lot of vehicles out there playing at being $4 X 4$ 's. They're small. Usually they're cute And sometimes, instead of going to the mall or the grocery store, they actually go off road. But you want a real all-terrain vehicle. One built to take everything you and nature can throw at it.

You want a Unimog.

Freightlıner Unimog, You Don't Need Roads When You Can Make Your Own (sales brochure on file with author). The brochure continues with a diagram of the Unimog depicting "what S.U.V.'s and other so-called $4 \mathrm{X} 4$ 's will see as you drive by." Id.

23 Freightliner Unimog, supra note 22.

24 For a more thorough treatment, see Kysar, supra note 15.

${ }^{25}$ See infra text accompanying notes 129-34. 
and energy to the project of devising practical, market-based policy tools to implement environmental regulatory goals. These tools have been thoroughly analyzed and promise workable solutions to concrete problems. The real mystery therefore would seem to lie in society's failure to employ them on a wider and more confident basis to combat widely acknowledged externalities. The discussion that follows attempts to explain that omission by identifying areas of tension in the competing preanalytic visions of ecological and conventional economics.

\section{A. Preanalytic Vision and the Emergence of Ecological Economics}

Conventional economists often state that growth of human economic production is not checked by restrictions imposed by nature. ${ }^{26}$ In other words, they treat the human economic process as an open system that draws resources and emits wastes through a relatively undefined and unexamined relationship with nature. In contrast, ecological economists view the means of production and nature as components of the same closed system. ${ }^{27} \mathrm{On}$ this account, the human economic process faces hard constraints imposed by the absolute or temporal scarcity of nonrenewable resources and renewable resources, as well as by the limited capacity of ecological mechanisms to absorb the pollution produced by exploitation of those resources. As a consequence of such constraints, society must remain cognizant of the extent and quality of existing resource stocks, as well as the capacity for natural systems to absorb waste outputs created during the transformation of those stocks into human goods.

In a 1966 article entitled The Economics of the Coming Spaceship Earth, ${ }^{28}$ economist Kenneth Boulding first identified the competing preanalytic visions that form the heart of the present schism between conventional and ecological economists. In Boulding's view, mainstream economics reflected the notion of the "cowboy economy," 29 in which natural frontiers are seen as limitless, resources inexhaustible, and wastes innocuous. Under such a conception, increases in the sheer volume of economic activity, as

\footnotetext{
${ }^{26}$ Specifically, economists typically accept a Cobb-Douglas production function in which nature and man-made capital are treated as substitutes. See PAUL A. SAMUELSON \& WILLIAM D. NORDHAUS, ECONOMICS 519-20 (16th ed. 1998). In that manner, although specific types of natural inputs can in fact become scarce or depleted, no general scarcity of natural resources can constrain economic growth See, e.g., Robert M. SOlow, AN Almost PractiCal SteP TOWARd SUSTAINABILITY 8-9 (1992) ("It is of the essence that production cannot take place without some use of natural resources. But I shall also assume that it is always possible to substitute greater inputs of labor, reproducible capital [e.g., technology], and renewable resources for smaller direct inputs of the fixed resource.").

27 See DALY, supra note 16, at xii (noting that the "distinguishing characteristic [of ecological economics] is that it sees the economy as a subsystem of a larger ecosystem that is finite, non-growing, and materially closed, while open to a flow-through (throughput) of solar energy that is also finite and nongrowing").

${ }^{28}$ Kenneth E. Boulding, The Economics of the Coming Spaceship Earth, reprinted in VALUING THE EARTH: ECONOMICS, ECOlOGY, ETHICS 297 (Herman E. Daly \& Kenneth N. Townsend eds., 1993).

29 Id. at 303.
} 
measured by gross domestic product (GDP), would appear to be a logical and defensible goal for society to adopt. ${ }^{30}$ In other words, if there are no significant environmental or social repercussions to economic growth, then society should rather uncontroversially pursue growth as a means of increasing the total amount of wealth available for distribution among its members.

Boulding contrasted the cowboy economy with a "spaceman economy," 31 in which the earth is seen as a closed system necessitating careful focus on the consequences of human economic activity. Once humanity nears the maximum sustainable biological limit or carrying capacity of the "Spaceship Earth,"32 it must value resource flows qualitatively, with specific reference to their ability to become enduring, efficient, and useful capital stocks, rather than simply value them quantitatively as an assumed proxy for increasing human welfare. As Boulding put it, " $[t]$ he essential measure of the success of the economy is not production and consumption at all, but the nature, extent, quality, and complexity of the total capital stock, including in this the state of the human bodies and minds included in the system. ${ }^{\prime 33}$ Focusing on the sheer magnitude of income flows jeopardizes the environment on which humanity ultimately depends and, in any event, provides only an indirect indicator of social welfare by equating material progress with human progress.

Boulding's vision of the earth as a closed system received scientific support in Nicholas Georgescu-Roegen's application of theoretical physics to economics. ${ }^{34}$ By illustrating how the laws of thermodynamics govern the use of resources within economic processes, Georgescu-Roegen provided a scientific explanation for Boulding's commonsense view that natural resources are limited: such resources are limited because their use necessarily entails their dissipation. According to the Second Law of Thermodynamics, matter-energy irrevocably moves from a condition of low- to highentropy or from ordered, available energy to chaotic, unavailable energy. Thus, in terms of matter-energy conservation, "the cost of any biological or economic enterprise is always greater than the product." ${ }^{35}$ For economics, the theoretical implication of the Second Law of Thermodynamics is fundamental. Rather than isolated as an exchange loop capable of perpetual expansion, the economic process must be viewed as fixed to a base of materials that inevitably tends to exhaustion in the long run.

${ }^{30}$ See id. at 303-04 ("It there are infinite reservoirs from which material can be obtained and into which effluvia can be deposited, then the throughput is at least a plausible measure of the success of the economy.").

31 Id. at 303.

32 Id. at 297.

33 Id. at 304.

34 Nicholas Georgescu-Roegen, The Entropy Law and the Economic Problem (Univ. of Ala., Distinguished Lecture Series No. 1, 1971), reprinted in VALUING THE EARTH, supra note 28, at 75

35 Id. at 80 . 
Just as Boulding's and Georgescu-Roegen's early works provided the intellectual foundation of ecological economics, Garrett Hardin's famous 1968 article The Tragedy of the Commons ${ }^{36}$ provided the discipline's transdisciplinary focus. The basic theme of Hardin's article had been well explored over a decade earlier by an economist. ${ }^{37}$ Both authors focused on the collective action problem posed by resources that are open to exploitation by any member of society without social, legal, or other forms of constraint. Hardin's eloquent article had a more far-reaching impact, however, precisely because his approach was not restricted to a purely economic inquiry. Rather, he fused his elementary economic reasoning with insights from biology, philosophy, and sociology. Thus, Hardin's article encouraged the type of transdisciplinary thinking that uniquely has characterized ecological economics in the decades following its publication.

Subsequent authors have seriously challenged Hardin's notion that commons dilemmas can be solved only through legislative controls ${ }^{38}$; nevertheless, his enduring contribution has been to demonstrate the sheer pervasiveness of commons dilemmas. For many, the collective action problem had been seen as a relatively minor behavioral exception to the general rule of allocative market efficiency. ${ }^{39}$ In Hardin's view, however, the commons tragedy was pervasive, and helped to explain a host of urgent contemporary problems, such as the extinction of marine life, ${ }^{40}$ the pollution of air and water, ${ }^{41}$ and the rapid growth of the human population. ${ }^{42}$ In this regard, Hardin transformed the tragedy of the commons from a curious anomaly to a more fundamental problem that necessitated a wholesale rethinking of the conventional economic model. In many respects, the discipline of ecological economics can be seen as an attempt to fill the theoretical vacuum created by Hardin's recognition of the ubiquity of collective action problems.

\footnotetext{
${ }^{36}$ Garrett Hardin, The Tragedy of the Commons, 162 SCI. 1243 (1968).

${ }^{37}$ H. Scott Gordon, The Economic Theory of a Common-Property Resource: The Fishery, $62 \mathrm{~J}$. POL. ECON. 124 (1954).

38 In his article, Hardin called for "mutual coercion, mutually agreed upon by the majority of the people affected" to circumvent the tragedy. Hardin, supra note 36, at 1247. Many subsequent commentators have critiqued this recommendation for ignoring altemative, less coercive approaches. See, e.g. ELINOR OSTROM, GOVERNING THE COMMONS: THE EVOLUTION OF INSTITUTIONS FOR COLLECTIVE ACTION (1990) (reviewing examples of common property regimes in which commons dilemmas are controlled by communal management, rather than formal legislation or individual ownership); Rose, supra rote 7, at 71-72 (noting that Hardin failed to observe both norm-driven solutions such as common property regimes and hybrid-property solutions such as tradable permits)

${ }^{39}$ Cf. David R. Hodas, The Role of Law in Defining Sustainable Development: NEPA Reconsidered, 3 WidEner L. SYMP. J. 1, 25-26 (1998) ("Current law mirrors the view of most economists that environmental externalities are an inconvenient theoretical contaminant in an otherwise elegant market system. Externalities are only an afterthought in a legal system driven by an individual/market oriented paradigm.").

${ }^{40}$ Hardin, supra note 36 , at 1245.

41 Id.

42 Id. at 1246.
} 
Building on these early contributions, economist Herman Daly has devoted his career to providing a more formal theoretical framework for analyzing the intersection of ecological and anthropic spheres. Most fundamentally, he recognized the concept of "scale," which refers roughly to "the physical scale or size of the human presence in the ecosystem, as measured by population times per capita resource use."43 Theoretically, society may pursue an entire range of scales, including ones so minimalist in their resource use as to inappropriately deprive humans of present utility, and ones so profligate in their consumption as to jeopardize the very future of the species. Daly holds the position that the optimal scale of the human economy is a sustainable one. ${ }^{44}$ That is, as a normative matter, governments should regulate the scale of the economy so that it requires no more resources or produces no more wastes than can be regenerated or absorbed, respectively, by the environment. In this manner, governments can provide future generations with an ecological context that, at least theoretically, will continue to support present standards of living.

\section{B. Scale as an Independent Concept}

An obvious rebuttal to the contentions of ecological economists is to point out that GDP can increase, and often has increased, without requiring corresponding increases in the degree of resource use in the economy; hence, infinite growth in GDP does not necessarily entail an unsustainable burden on the environment. ${ }^{45}$ This argument, however, merely embraces the ecological economist's goal of pursuing "development," defined as welfare enhancements that do not entail increases in the economy's ecological burden, ${ }^{46}$ rather than a less refined pursuit of economic growth without attention to its ecological consequences. In previous eras, it may have been appropriate to ignore the differences between growth and development on the assumption that any increase in consumption, material or nonmaterial, was an improvement in human welfare. In the "spaceman economy," however, it becomes necessary to distinguish between those types of economic expansion that tax the ecosystem more than the benefits they create and those that do not. In the ecological economist's view, only the latter should be maximized.

For these reasons, Daly contends that scale should have a separate, formalized presence within the economic pantheon, just as wealth distribution has an independent conceptual significance. ${ }^{47}$ Markets, through their twin

\footnotetext{
43 Herman E. Daly, Beyond Growth 50 (1996).

${ }^{44} \mathrm{Id}$. at 52 (noting that "[s]ustainability is probably the characteristic of optimal scale on which there is most consensus").

${ }^{45}$ See Mark Sagoff, Carrying Capacity and Ecological Economics, 45 BIOSCI. 610, 614 (1995).

46 See DALY, supra note 43 , at 69 ("[G]rowth in GNP [gross national product] . . . is a conflation of ... two processes: (1) growth (physical increase) and (2) development (qualitative improvements that allow more stock maintenance per unit of throughput, and more service per unit of stock).").

47 Id. at 51 .
} 
devices of price information and economic incentives, are unparalleled in their effectiveness at allocating resources efficiently. They do not, however, resolve the altogether separate problems of achieving distributive justice and ecological sustainability. Put differently, economists recognize that a Paretooptimal allocation of resources can be achieved with respect to any given distribution of income, including ones that might be described as unjust. ${ }^{48}$ Similarly, a Pareto-optimal allocation of resources can be achieved with respect to any given scale of the human economy, including ones that might lead to ecological peril. "Ecological criteria of sustainability, like ethical criteria of justice, are not served by markets." 49 Thus, Daly argues that "[o]ptimal scale, like distributive justice, full employment, or price level stability, is a macroeconomic goal," ${ }^{50}$ requiring unique macroeconomic policy instruments.

The tradable permit provides a helpful example of such instruments. As noted above, ${ }^{51}$ economists have long recognized that uninhibited access to fisheries presents a collective action problem that may lead to rapid and unsustainable depletion of fish populations. One policy tool well designed to control such social traps is the tradable permit system. ${ }^{52}$ Governments first determine the appropriate aggregate number of permits to issue in a given year by referencing the best available scientific estimates of the maximum sustainable yield from the fishery in question. Next, governments distribute the fishing rights among their citizens according to essentially moral criteria regarding the desirable distribution of property rights. ${ }^{53}$ Finally, governments encourage trading of the fishing permits in order to ensure that they are employed in the most efficient manner possible. Thus, the simple policy instrument of tradable permits forces separate judgments by lawmakers and regulators regarding the sustainable scale of economic activity, the just distribution of economic rights, and the efficient allocation of economic resources.

Of course, both conventional and ecological economists widely endorse tradable permits for implementation of regulatory goals. ${ }^{54}$ The impor-

${ }^{48}$ Amartya Sen provides the classic, if charged, formulation: "[A] society or an economy can be Pareto-optimal and still be perfectly disgusting." AMARTYA SEN, COLLECTIVE CHOICE AND SOCIAL WELFARE 22 (1970).

49 DALY, supra note 43 , at 32.

50 Id. at 51 .

51 See supra text accompanying note 37.

52 See TOM TEITENBERG, ENVIRONMENTAL AND RESOURCE ECONOMICS 296-300 (5th ed. 2000).

53 More realistically, governments attempt to navigate a treacherous sea of rent-seekıng constituents. See infra note 56.

${ }^{54}$ See Carol M. Rose, The Several Futures of Property: Of Cyberspace and Folk Tales, Emission Trades and Ecosystems, 83 MINN. L. REv. 129, 163-66 (1998) (describing academic support for "hybrid property" solutions such as tradable permits to commons dilemmas); see also Richard B. Stewart, Environmental Regulation and International Competitiveness, 102 YALE L.J. 2039, 2093-97 (1993) (arguing for tradable emissions rights); James E. Krier, Marketable Pollution Allowances, 25 U. TOL. L. REV. 449 (1994) (analyzing "hybrid property rights" for emission allowances); Robert W. Hahn \& Robert N. Stavins, Incentive-Based Environmental Regulation: A New Era from an Old Idea?, 18 ECOLOGY L.Q. 1 (1991) (same). 
tant point, though, is that the conventional account still tends to view the tragedy of the commons as an exception to the general rule that allocative efficiency, coupled with some redistributive tax-and-transfer system, represents the entirety of what policymakers must monitor. For whatever reason, a broader appreciation of scale has not flowed from recognition of "the fisherman's problem." 55 Yet the commons dilemma of open-seas fisheries is simply an exceptionally sharp rendering of the problem of scale that plagues every aspect of human economic activity. In the view of ecological economists, society always faces a question of how much of an economic activity to conduct, in addition to how efficiently it should be conducted and how equitably the resulting economic gains should be distributed.

In the context of a renewable stock like fisheries, where the optimal yield can be defined as a sustainable one, such judgments of scale seem tractable, perhaps even simple. ${ }^{56}$ In the context of more fundamental decisions about optimally balancing the size of a population with its opportunities for affluence, however, governments must face ethical judgments far more troublesome than they have grown accustomed to resolving. The modern political-economic means of pursuing distributive justice frequently has been to increase "the size of the pie." ${ }^{77}$ So long as policymakers and the public view economic expansion as environmentally costless, the problem of inequitable distribution can be kept at bay by the promise of individual opportunity within a growing economy. At some point, however, ecological economists argue that further growth in the scale of the economy will create more costs than benefits and, hence, growth no longer will be available as a no-lose political expedient to problems of inequitable resource distribution. Instead, society will need to confront such problems directly, along with similarly troublesome questions about population size, the other primary determinant of scale.

\section{Ecological Economics as an Independent Methodology}

A frequent and important counterargument to the contentions of ecological economists is that, rather than being forced to confront such crushing dilemmas, society instead can safely disregard the concept of scale given that the market will self-correct for any ecological scarcities that happen to arise, whether as a consequence of human activity or not. According to this account, as any good becomes scarce, markets signal its scarcity through price increases, thereby prompting conservation efforts, techno-

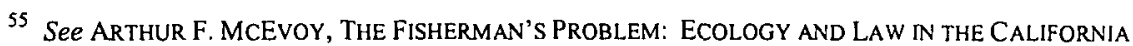
FISHERIES 1850-1980 (1986).

${ }^{56}$ Of course, implementation of fishery permit systems may be complicated by interest group disputes over the proper scientific estimate of the amount of permits to be issued and the political decision of how to allocate the valuable property rights. See generally Shi-Ling Hsu \& James E. Wilen, Ecosystem Management and the 1996 Sustainable Fisheries Act, 24 ECOLOGY L.Q. 799 (1997). As a theoretical matter, however, a diverse array of interested parties seem likely to agree that the optimal scale of fishing activities is a sustainable one.

57 See DALY, supra note 43, at 51 . 
logical innovations, recycling efforts, substitution, and other limit-avoiding reactions. ${ }^{58}$ In this manner, and arguably consistent with the experience of humanity to date, ${ }^{59}$ markets devise ingenious means of circumventing natural constraints such that legislated controls on the scale of the macroeconomy become unnecessary. This subpart reviews three counterarguments to this belief in the self-correcting power of the market.

1. Externalities and the Limits of Knowledge.-First, ecological economists hasten to point out that optimal human development will not be achieved by reliance on market forces alone, given the number and variety of environmental externalities that undermine the efficacy of the price mechanism. For instance, the market may well produce "substitutes" for breathable air when local environments become toxic. ${ }^{60}$ That does not mean, however, that polluted air and portable breathing devices are preferable to the free intake of clean air. The market decisions eventually resulting in such a polluted state of affairs will not have taken account of the costs of pollution along the way. Such systemic externalization renders doubtful any reliance on the unfettered market to regulate the scale of the human presence within the ecological universe.

Economists have long recognized that externalities can impede optimal market outcomes in this manner. In the view of ecological economists, however, the conventional responses to such market failures-adoption of Pigouvian taxes ${ }^{61}$ or institution of Coasean property rights ${ }^{62}$-may not ade-

58 See, e.g., Robert M. Solow, The Economics of Resources or the Resources of Economics, 64 AM. ECON. REV. 1, 8-9 (1974).

59 See generally BJøRN LOMBORG, THE SKEPTICAL ENVIRONMENTALIST (2001) (reviewing an artay of empirical evidence suggesting that doomsday scenarios proffered by 1970 s era environmentalists have not come to pass).

${ }^{60}$ See Kysar, supra note 15, at 53.

${ }^{61}$ Generally speaking, Pigouvian tax schemes attempt to internalize costs by imposing a tax on the actuvity that is seen as giving rise to the externality. In that manner, the taxed party can determıne whether its activity is cost-justified in light of the full social costs that the activity entalls. See infra text accompanying note 139 .

62 One of Ronald Coase's important contributions was the insight that externalities result from a reciprocal relationship between two parties, rather than the activities of a singular party. See generally Ronald H. Coase, The Problem of Social Cost, 3 J.L. \& ECON. 1 (1960). Thus, instead of taxing one party for the amount of an externality, Coasean property rights schemes attempt to define property rights and reduce impediments to bargaining, such that the affected parties themselves can decide whether to restrict activities through private trading of the rights. See Stewart J. Schwab, Coase Defends Coase: Why Lawyers Listen and Economists Do Not, $87 \mathrm{MrCH}$. L. REV. 1171, 1185 (1989). A related stream of literature argues that such Coasean property rights solutions often will evolve naturally through market processes as technologies develop to lower the cost of creating and enforcing property rights. See, e.g., Harold Demsetz, The Exchange and Enforcement of Property Rights, 7 J.L. \& ECON. 11, 14 (1964); Harold Demsetz, Toward a Theory of Property Rights, 57 AM. ECON. REV. 347 (Pap. and Proc. 1967); Terry L. Anderson \& P.J. Hill, The Evolution of Property Rights: A Study of the American West, 18 J.L. \& ECON. 163 (1975); GARY D. LIBECAP, CONTRACTING FOR PROPERTY RIGHTS (1989); TERRY L. ANDERSON \& DONALD R. LEAL, FREE MARKET ENVIRONMENTALISM (1991); Bruce Yandle \& Andrew P. Morriss, The Technologies of Property Rights: Choice Among Alternative Solutions to Tragedies of the Commons, 28 ECOLOGY L.Q. 123 (2001). 
quately grapple with the type of externalities that humanity actually faces. According to ecological economists, such policy instruments, although certainly preferable to a status quo of unexamined cost externalization, are nevertheless insufficient by themselves to maintain human impact within ecologically sustainable parameters, most critically because of the informational demands entailed by the regulatory approach. Although textbook policy discussions may assume complete knowledge regarding the type of environmental harm to be addressed, in reality physical scientists do not purport to adequately understand ecosystem goods and services, either in isolation or in their complex web of interdependence. ${ }^{63}$ Without such knowledge, both regulators designing environmental tax schemes and parties attempting to bargain over property rights will be limited in their ability to account for environmental harms.

Furthermore, what scientists do appear to know is that natural capital is not destroyed or depleted in order of increasing importance to humanity. To give just one example, humans may face immense costs from climate change long before petroleum reserves are depleted. Such nonlinear natural cost functions make the institution of internalizing tax schemes all the more challenging for regulators. Similarly, parties attempting to coordinate Coasean property-rights solutions to environmental externalities may face severe difficulties in the timing of their bargaining. The externalized costs of carbon emissions, for example, may escalate rapidly and dramatically as complex environmental feedback loops become self-perpetuating. Scientists speculate that incremental increases in ocean temperatures could eventually cross a threshold that would lead to the release of billions of tons of trapped methane gas in polar ice cap regions, an event that could entail climate shifts on a massive scale. ${ }^{64}$ Given the great uncertainty regarding such predictions, individuals and entities affected by climate change may only sit down to the bargaining table after atmospheric dynamics have reached a point of irreversibility. ${ }^{65}$

In addition to depending on adequate scientific knowledge, the implementation of environmental taxes also assumes that reliable mechanisms exist for valuing ecosystem goods and services. One must, after all, transform pollution and other externalities into some pecuniary value that is then "internalized." But the manner, and indeed the propriety, of making such calculations are far from uncontroversial..$^{66}$ Coasean property rights solu-

63 See Salzman et al., supra note 15 , at 327.

64 See Kysar, supra note 15, at 2-3.

65 Moreover, for many of the most significant environmental dilemmas, property rights solutions simply will be infeasible, either because the property rights themselves are incapable of enforcement or because the parties affected by the relevant environmental externalities are unable to surmount massive bargaining costs in order to ensure efficient allocation of property rights. See Terry L. Anderson \& Donald R. Leal, Free Market Environmentalism: Hindsight and Foresight, 8 CORNELL J.L. \& PUB. POL'Y 111, 128-30 (1998).

66 See Heinzerling, supra note 7, at 306-07. 
tions attempt to circumvent such constraints by putting the valuation decision into the hands of market actors. Yet the actors likely to face the most severe consequences of environmental degradation, namely future generations, are not represented in the bargaining process ${ }^{67}$ The most one can hope is that some currently living market actors will express-through their willingness to pay - their best judgment of what value future generations will place on the environmental good or service. But surely that view requires an unrealistic degree of altruism on the part of current market participants.

In short, ecological economists believe that fine tuning the price mechanism as a response to problems of scale "requires heroic assumptions about our knowledge of the external costs resulting from ecosystem disruption, and how these costs are imputed to the micro decisions that gave rise to them." 68 As will be seen in Part II, many of the same critiques may be made against ecological economics, once the discipline moves from theoretical debate to practical implementation. Nevertheless, a key advantage of the transdisciplinary approach adopted by ecological economics is that it remains keenly attuned to recognizing the circumstances under which such difficult and imprecise valuation is required. That is, ecological economists expect human economic activity to impact ecosystems in myriad unpredictable and significant ways. Such interactions are not viewed as an exception to the theoretical model requiring ex post accommodation as an "externality." Rather, they are central to the discipline's very existence.

2. Discounting as an Imperfect Proxy for Social Judgment.-A second ecological economic response to the contention that markets will adequately resolve scale dilemmas points out that some components of the disutility caused by environmental externalities simply cannot, as a matter of logic, be internalized by the price mechanism. With respect to Pigouvian taxes, for instance, even assuming that ecologists, biologists, and physicists could perfectly predict the environmental harms a particular market event will cause, and that economists could perfectly monetize such harms in a socially agreeable manner, the price mechanism still could not subsume the fundamentally moral judgment that must be made with regard to environmental harms imposed on future generations. When implementing an environmental tax scheme, decisionmakers must not only measure harms suffered by future generations, but they also must translate those harms into a value that can be considered in the present. Such translation is typically accomplished by determining algebraically the amount of money that would need to be set aside today in order to accumulate, through compounded interest, the full amount of the measured harm in the future. The necessity of

\footnotetext{
67 See EDITH BROWN WEISS, IN FAIRNESS TO FUTURE GENERATIONS: INTERNATIONAL LAW, COMMON PATRIMONY AND INTERGENERATIONAL EQUITY (1989).

68 DALY, supra note 43 , at 54.
} 
choosing an appropriate discount rate for such calculation, however, imposes a logical roadblock to subsuming scale considerations within the price mechanism. ${ }^{69}$

For instance, government agencies often look to market rates for financial instruments when selecting a discount rate for regulatory decisionmaking. ${ }^{70}$ However, market rates of interest, like other forms of price, are dependent on the initial distribution of property rights. Each distribution of resources between generations determines a different efficient allocation of resources, which in turn gives rise to a different set of prices and interest rates. ${ }^{71}$ Thus, relying on market rates of interest to determine questions of intergenerational resource distribution puts the conceptual cart before the horse. Nor does the so-called "social discount rate"72 avoid these problems. The social discount rate posits that society first should determine an ethically appropriate rate of discounting and then allow the selected rate to guide regulatory decisionmaking that impacts future generations. Joseph Stiglitz expresses this position as follows: "[I]f the government correctly controlled the rate of interest (the savings rate) then there would be no objection to the competitive determination of the rate of utilization of our natural resources." 73 No consensus has emerged, however, regarding how the government can "correctly" control the rate of interest.

Even if such a consensus did emerge, utilizing a social discount rate would entail the same problem of conceptual bootstrapping as does relying on market rates of interest. Society's judgment of the ethically appropriate rate of discounting would no doubt change once it becomes known which generation owns what resources. In other words, the set of distributive outcomes determined by the previously agreed upon social discount rate would necessitate a new rate, which would result in a new set of distributive outcomes necessitating still another rate, and so on. Support for this proposition can be inferred from the intense debate that has in fact surrounded the choice of an appropriate discount rate for use by federal agencies to reduce future economic impacts of regulations to a present value for cost-benefit

69 See Lewin, supra note 15, at 274; Lisa Heinzerling, Discounting Our Future, 34 LAND \& WATER L. REV. 39 (1999) [hereinafter Heinzerling, Discounting Our Future]; Lisa Heinzerling, Environmental Law and the Present Future, 87 GEO. L.J. 2025 (1999); Lisa Heinzerling, Discounting Life, 108 YALE L.J. 1911, 1915 (1999); Richard L. Revesz, Environmental Regulation, Cost-Benefit Analysis, and the Discounting of Human Lives, 99 COLUM. L. REV. 941, 947-48 (1999).

${ }^{70}$ See Revesz, supra note 69 , at $977-81$.

71 See Richard B. Norgaard \& Richard B. Howarth, Sustainability and Discounting the Future, in ECOlogical ECONOMICS: THE SCIENCE AND MaNAGEMENT of Sustainability 88, 97-98 (Robert Costanza ed., 1991).

72 Solow, supra note 58 , at 10.

73 Joseph E. Stiglitz, Growth with Exhaustible Natural Resources: The Competitive Economy, 41 REV. ECON. STUD. 139, 139 (1974). 
analysis. ${ }^{74}$ Broad academic or public agreement on an appropriate discount rate may remain elusive precisely because, in many regulatory contexts, selection of a discount rate seems trivial in comparison to the underlying distributive judgment that the discount rate is attempting to subsume. In other words, faced with the question, "At what rate should future demand for swordfish be discounted when using cost-benefit analysis to set harvest rates?" many people likely would respond, "At whatever rate results in a sustainable stock of swordfish." The fact that harvest rates are not set using discounted future willingness to pay for fish ${ }^{75}$ demonstrates that, with respect to the fishery at least, society has recognized that a distributive judgment must logically precede the use of discounting to aid allocative efficiency. Questions of intergenerational distribution, like questions of intragenerational distribution, simply cannot be subsumed within the allocative function of the market.

Coasean property rights solutions, as traditionally understood, do not circumvent this conceptual limitation. Under a Coasean scheme, private owners still must make market decisions that have significant ramifications for future generations, but they must make such decisions under the discipline of market rates of interest. ${ }^{76}$ Any decision to defer resource consump-

74 In its role as overseer of cost-benefit analyses conducted by federal agencies, the Office of Management and Budget has suggested discount rates of ten and seven percent to reduce future harms and

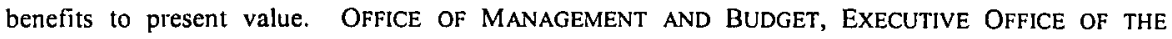
PRESIDENT, CiRCUlaR A-94, at 4 (1972) (ten percent); Benefit-Cost Analysis of Federal Programs; Guldelınes and Discounts, 57 Fed. Reg. 53519, 53523 (1992) (seven percent). As Lisa Heinzerling notes, however, studies that attempt to estimate the social discount rate through market behavior, experimental surveys, the rate of return on financial instruments, and other methods achieve results that range from as low as one half of one percent to as high as ninety percent. See Heinzerling, Discounting Our Future, supra note 69 , at 44 . In short, "the correct discount rate is always a matter of controversy." Jon D. Hanson \& Kyle D. Logue, The Costs of Cigarettes: The Economic Case for Ex-Post IncentiveBased Regulation, 107 YALE L.J. 1163, 1234 n.307 (1998) (quoting WILlaRD G. MANNING ET AL., THE COSTS OF POOR HEALTH HABITS 8 (1991)) (internal quotations omitted).

75 Under the Magnuson and Stevens Fishery Conservation and Management Act, Congress expressly found that "[f]ishery resources are finite but renewable," and that "[i]f placed under sound management before overfishing has caused irreversible effects, the fisheries can be conserved and maintained so as to provide optimum yields on a continuing basis." 16 U.S.C. $\$ 1801$ (a)(5) (2000). Optimum yield is defined as "the maximum sustainable yield from [a given] fishery," adjusted as approprate for other "social, economic, or ecological factor[s]." Id. §1802(28)(B). Slippage away from the goal of sustainability is seemingly constrained by the proviso, "in the case of an overfished fishery, [optimum yield] provides for rebuilding to a level consistent with producing the maximum sustainable yield in such fishery." Id. $\S 1802(28)(C)$. Thus, the Act makes a fairly unambiguous distributive judgment that fishery stocks should be maintained at sustainable levels. The judgment is made directly: sustainability is not contingent on the selection of an accommodating discount rate, but rather is made an express arm of the Act. The argument of ecological economists is that, not only fishery management decisions, but all questions of intergenerational natural resource distribution should be made according to this type of direct deliberation.

76 Economist Harold Hotelling made this point in one of the most enduring articles from natural resource economics. See Harold Hotelling, The Economics of Exhaustible Resources, 39 J. POL. ECON. $137(1931)$. 
tion in favor of future generations must be weighed by the resource owner against the return that proceeds from present consumption would generate in alternative investments. Such a decisionmaking process, again, fails to answer the logically prior question of how natural resources ought to be distributed across time to achieve intergenerational equity.

Ecological economists do believe that discounting can be an appropriate means for determining how the present generation's resources should be allocated to maximize the efficiency with which it uses those resources. ${ }^{77}$ However, such allocation must take place separate from and subsequent to collective social judgments regarding the distribution of resources between generations. Using discounting as the method for achieving intergenerational distributive equity opens all resources to present consumption by taking as given a state of distribution involving total ownership by the present generation-the very question to be decided. For that reason, ecological economists like Daly rely on modified Coasean policy instruments, such as tradable permits, that make questions of intergenerational distribution and sustainable scale explicit within the decisionmaking process. By setting aggregate permit levels equal to the maximum sustainable yield from a given fishery, for instance, policymakers make an openly normative judgment that fish populations should be maintained at levels sufficient to ensure their continued availability to future generations. Such a judgment is fundamentally market-determining, not market-determined. That is, the decision to preserve fish populations depends directly on whether society wants it to happen, not on whether the discount rate allows it to happen.

3. Individual Versus Collective Decisionmaking.-Finally, putting aside the practical and logical difficulties of subsuming scale considerations within the price mechanism or within private bargaining over property rights, ecological economists argue that using either policy tool to regulate scale remains an inappropriately individualistic mechanism for making what is, unavoidably, a collective judgment. For instance, pure Coasean property-rights solutions require private actors to assert their willingness to pay to avoid environmental harms through market interactions. Yet for many of the most pressing environmental issues, such bargaining necessarily becomes collective in nature, given the numerous and diverse groups that will be affected. At some point, the prospect of millions of people engaging in private bargaining over environmental harms, such as global climate change, becomes indistinguishable from public lawmaking.

Similarly, Pigouvian tax schemes often seem stretched beyond reason when applied to environmental issues with potentially worldwide, long-term, irreversible effects. In the global warming context, for instance, such an ideal tax would require some more or less contrived means of polling present and future generations to determine the value that they place on the threatened

77 See DALY, supra note 43, at 56. 
ecological impacts of global warming, in all of the numerous and disparate forms that scientists have identified as possibilities. It would require transforming those valuations into a tax that is first imposed on certain primary activities such as electricity production and then shifted downstream onto every human choice or activity that gives rise, directly or indirectly, to the emission of greenhouse gases. And for what purpose must these calculations and assessments be made? In a sense, to extract a judgment about the fate of the world from the flip of a light switch. To view every minute behavioral choice as revealing a vote about vital systemic costs of collective action that may threaten the ability of future generations even to subsist.

Given the daunting and at least arguably incoherent nature of this task, the ecological economist instead focuses on the question of scale directly. Why not determine, from an ecological and a social perspective, how large the human macroeconomy ought to become and institute direct macrolevel controls to achieve that scale? Such an approach seems more appropriate than attempting to divide and assign such macrolevel questions to billions of microlevel decisions that have little or nothing to do with the larger issue at the moment of choice.

4. Summary.-Standard economic theory and ecological economic theory both divide the world into separate categories of fixed and manipulable factors. Standard economics treats-nonmaterial factors such as preferences and income distribution as given. The economist's task then is to ensure that material factors, such as capital and goods, are most efficiently employed to suit the given nonmaterial parameters. In practice, the adjustment of material factors generally entails economic growth, often through increasing exploitation of natural resources. Ecological economists, in contrast, take the physical environment as fixed and contemplate mechanisms for adjusting nonmaterial factors to best suit the given ecological superstructure. That is, ecological economists study "how the nonphysical variables of technology, preferences, distribution, and lifestyles can be brought into feasible and just equilibrium with the complex biophysical system of which we are a part." 78 Such adjustment entails the enhancement of resource productivity and the just distribution of wealth and income, all within the context of a steady-state, or non-physically expanding, economy.

Admittedly, the hallmark policy instrument reviewed in the preceding sections-the tradable permit-is not novel. ${ }^{79}$ What is new and valuable

\footnotetext{
78 Id. at 4.

79 It should be noted, however, that the tradable permit appears to have received its earliest expression in the work of an ecological economist. Although generally traced to Canadian economist J.H. Dales, see Heinzerling, supra note 7, at 302 (citing J.H. DALES, POLLUTION, PROPERTY AND PRICES (1968)), the tradable permit actually seems to have originated in the work of ecological economist Kenneth Boulding, whose proposal for tradable reproductive rights as a means for achieving population control preceded Hale's proposal by four years. See DALY, supra note 43, at 56 (describing it as "the first clear exposition of the logic of the [transferable licenses] scheme, although applied to the least likely area of acceptance politically" (citing KENNETH E. BOULDING, THE MEANING OF THE TWENTIETH CENTURY (1964))
} 
from ecological economics, though, is the presence of a preanalytic vision that gives coherence to the tradable permit analysis. The standard fishery permit analysis is compelling because so many commentators have recognized the problem of scale inherent in exhaustible resources like fish populations. Once commentators perceive the problem of scale as universal to human economic activity, however, a more integrated vision of how such activity impacts the welfare of humans, other species, and the earth itself will need to replace conventional economics. This vision will need to be one that facilitates deliberation about the scale of all types of activity; one that attempts to integrate not merely efficiency into the discussion, but also problems of distribution and sustainability; one that refuses to treat vital scientific, ethical, and political issues as exogenous to its analysis; one that, in short, provides a sound basis on which to guide policy in a full world. Ecological economics provides such a vision. The next Part provides an overview of how an ecological economic analysis of law and public policy might appear if the vision of ecological economists was adopted by legal scholars interested in questions of environmental import.

\section{ECOLOGICAL ECONOMIC ANALYSIS OF LAW}

In recent years, legal economic scholars-Steven Shavell and Louis Kaplow most notably-have argued that analysis of jurisprudential decisionmaking should focus on efficiency rather than on notions of distributive equity or fairness. ${ }^{80}$ That is, common-law judges should construct legal rules to achieve optimal allocation of resources among competing uses, without concern for the distributional effects of such rules. The reasoning behind this approach is relatively straightforward: for every inefficient but desirably redistributive legal rule, one can imagine an alternate legal rule, coupled with a redistributive tax scheme that would achieve the same desired wealth transfer without the efficiency loss. For that reason, along with its comparative administrative advantage at transferring wealth, the tax-andtransfer system, it is argued, should be the exclusive means for the government to address distributional concerns.

While it may be true that "any regime with an inefficient [but redistributive] legal rule can be replaced by a regime with an efficient legal rule and a modified income tax system designed so that every person is made better off," 81 the modified income tax system necessary to ensure that such

80 See Steven Shavell, A Note on Efficiency vs. Distributional Equity in Legal Rulemaking: Should Distributional Equity Matter Given Optimal Income Taxation?, 71 AM. ECON. ASS'N PAPERS \& PROC. 414 (1981); Louis Kaplow \& Steven Shavell, Why the Legal System Is Less Efficient Than the Income Tax in Redistributing Income, 23 J. LEGAL STUD. 667 (1994) [hereinafter, Kaplow \& Shavell, Why the Legal System]; Louis Kaplow \& Steven Shavell, Should Legal Rules Favor the Poor? Clarifying the Role of Legal Rules and the Income Tax in Redistributing Income, 29 J. LEGAL STUD. 821 (2000); Louis Kaplow \& Steven Shavell, Fairness Versus Welfare, 114 HARV. L. REV. 961 (2001) [hereinafter, Kaplow \& Shavell, Fairness Versus Welfare].

81 Kaplow \& Shavell, Why the Legal System, supra note 80, at 669. 
a Pareto improvement actually eventuates may not be possible within a given political climate. As a practical matter, therefore, Shavell and Kaplow's argument may demonstrate only that potential Pareto improvements may be gained by excluding distributive effects from the selection of legal rules. Their reasoning does not address whether legal decisionmakers should continue to ignore distributional effects when it is not confidently known that the "modified income tax system" will be adopted-that is, when it is not known that the redistribution necessary to achieve the Pareto improvement will occur. ${ }^{82}$

A similar analysis applies to the goal of sustainable scale. Although it has not appeared within the legal economic literature, one could make an argument against the consideration of scale effects of legal rules that tracks Shavell and Kaplow's contention that the macroeconomic goal of equitable distribution is best addressed through comprehensive legislative schemes such as the tax-and-transfer system. The same response, however, would apply: whether ignorance of scale effects is justified in the face of legislative recalcitrance is a separate, and more difficult, question. Indeed, with respect to scale, the situation is more problematic because no mechanism analogous to the tax-and-transfer system currently exists to regulate the physical scale of the economy. Achieving a sustainable scale of the human economy is left as a macroeconomic goal better addressed through unique, macroeconomic policy instruments; yet no such instruments are in place.

Moreover, one popular response to the distribution question, which holds that growth in the scale of the economy will raise absolute wealth levels for all market participants, ${ }^{83}$ stands in tension with the goal of maintaining society's ecological footprint within sustainable parameters. In the view of ecological economists, the biophysical demands generally associated with economic growth have pushed the human economy toward unsustainable levels. Thus, once one accepts that the level of human economic activity is subject to absolute ecological constraints, the macroeconomic concerns of distribution and scale no longer can be pushed to the side in an ever-intensifying pursuit of growth.

For at least two reasons, therefore, legal theorists might benefit from incorporating the findings of ecological economists into their analysis, not merely with respect to policy formulation and legislative decisionmaking, but also with respect to common-law rulemaking. First, because no political mechanism analogous to the tax-and-transfer system exists to regulate the scale of the macroeconomy, scholars cannot confidently ignore the scale ef-

\footnotetext{
82 The authors are forthcoming about this limitation. Id. at 675 ("An argument sometimes offered in favor of redistribution through legal rules is that the tax system falls short of optimal redistributive taxation-perhaps because of the balance of political power in the legislature. This argument raises questions that we do not seek to address about the function of courts in a democracy."); Kaplow \& Shavell, Fairness Versus Welfare, supra note 80, at 995 n.66.

${ }^{83}$ See Martha Albertson Fineman, Contract and Care, 76 CHI.-KENT L. REV. 1403, 1435-36 (2001).
} 
fects of alternative legal rules in the way that some scholars have advocated ignoring distributive effects. Second, because the unrefined economic growth response to the distribution problem is in tension with the goal of sustainable scale, justifying the ignorance of both problems eventually will become untenable. In light of this possibility, legal scholars should address both problems now by allowing ecological economic insights to inform their analyses.

This Part attempts to contribute to that project by reviewing a variety of specific policy implications that flow from the theoretical framework of ecological economics. As explained in subpart B, scholars have proposed a number of regulatory instruments that address the issues of sustainability and scale in a comprehensive manner analogous to the tax-and-transfer system. Before turning to those instruments, subpart A briefly reviews some ways in which ecological economics might inform judicial as well as legislative decisionmaking.

\section{A. Assessing the Scale Effects of Common Law Rules}

Optimal maintenance of scale requires the type of comprehensive remedial measures that generally are considered legislative in nature. ${ }^{84} \mathrm{Nev}$ ertheless, the common-law rules adopted by judges also can impact the size and severity of the human presence within the ecosystem. Accordingly, judicial actions are an important component of the ecological economic analysis of law. This subpart reviews various ways in which common-law decisionmaking can be informed by ecological economic theory.

1. Preanalytic Vision and Default Principles in Property Law.-An oft-discussed pair of cases involving negative easements for light and air in property law ${ }^{85}$ captures the competing preanalytic visions embraced by conventional and ecological economics. In Fountainebleau Hotel Corp. $v$. Forty-Five Twenty-Five, Inc. ${ }^{86}$ a Florida appeals court rejected a nuisance complaint brought by a luxury hotel owner against another hotel, the expansion of which threatened to place the first hotel's pool area in shadow. The court noted that American jurisprudence does not recognize "a legal right to the free flow of light and air across the adjoining land of [one's] neighbor." 87 Instead, the background common-law rule, labeled the "universal rule" 88 by the court, is "that adjoining landowners have an equal right under the law to build to the line of their respective tracts and to such a height as is desired by them."89

84 See Lon L. Fuller, The Forms and Limits of Adjudication, 92 HARV. L. REV. 353 (1978).

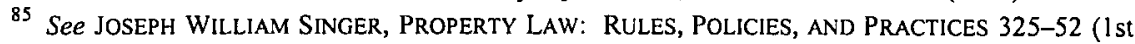
ed. 1993) (reproducing and discussing Fountainebleau Hotel Corp. v. Forty-Five Twenty-Five, Inc., 114 So. 2d 357 (Fla. Dist. Ct. App. 1959) and Prah v. Maretti, 321 N.W.2d 182 (Wis. 1982)).

86114 So. 2d 357 (Fla. Dist. Ct. App. 1959).

87 Id. at 359.

$88 \mathrm{Id}$. at 360 .

89 Id. 
In contrast, the Wisconsin Supreme Court in Prah v. Maretti ${ }^{90}$ recognized a common-law nuisance cause of action brought by a homeowner against his neighbor for obstruction of access to sunlight as a natural source of energy. Consistent with Fountainebleau, the "defendant assert[ed] that he has a right to develop his property in compliance with statutes, ordinances and private covenants without regard to the effect of such development upon the plaintiff's access to sunlight." 91 The court, however, departed from the traditional common-law rule, arguing that "the policy of favoring unhindered private development in an expanding economy is no longer in harmony with the realities of our society." 92

These two courts premise their decisions upon contrasting visions of human economic activity. ${ }^{93}$ Fountainebleau, by assuming that all structures other than fences erected purely for spite "serve[] a useful and beneficial purpose,"94 envisages the empty world of the cowboy economy in which development of land without regard to external consequences is a logical and defensible pursuit. Prah, in contrast, views land as limited in supply, such that one cannot ignore external harms caused by development on the assumption that abundant alternative resources are available for the aggrieved neighbor. In that regard, Prah could be said to represent the spaceman economy vision at the heart of ecological economics. When fashioning default rules regarding the use of land, therefore, common-law judges adopting an ecological economic approach would follow Prah and hold that, at least under appropriate circumstances, "obstruction of access to light might be found to constitute a nuisance."95

90321 N.W.2d 182 (Wis. 1982).

91 Id. at 188 .

92 Id. at 190 .

93 Admittedly, the cases also can be distinguished on factual grounds. For instance, unlike Fountainbleau, Prah involved both a defendant who had been advised of the plaintiff's need for access to sunlight prior to purchasing his lot and a plaintiff whose solar use was seemingly entitled to enhanced judicial protection fresh on the heels of the 1970 s energy crisis. Nevertheless, as noted in the text, the opinions also seem to evince contrasting background assumptions regarding the general avalability of land and assumed benefits of development.

94114 So. 2d at 359.

95321 N.W.2d at 191. Of course, in the pure Coasean setting, neither rule will affect the eventual allocation of rights to use the land. See Coase, supra note 62 . In the less pure world of actual bargaining, however, the very selection of a default rule creates an entitlement that may alter people's valuation of the subject resource. See Elizabeth Hoffman \& Matthew L. Spitzer, Willingness to Pay vs. Willingness to Accept: Legal and Economic Implications, 71 WASH. U. L.Q. 59, 104-05 (1993); Jeffrey J. Rachlinskı \& Forest Jourden, Remedies and the Psychology of Ownership, 51 VAND. L. REV. 154l, 1551 (1998) ("Even excluding transaction costs, the allocation of a right is 'stickier' than Coase had assumed."). Thus, a common law judge who follows Prah may not only provide judicial recognition of the ecological economic worldview, but may also alter the resulting allocation of rights among the parties. As Jeffrey Rachlinski and Forest Jourden demonstrate, this will be particularly true when the interest in sunlight access is protected by injunctive relief, as opposed to a mere damages remedy. See id. at 1574-75 (concluding that psychological attachment to legal rights is stronger when rights are protected by property rules, as opposed to liability rules). 
As John Sprankling has argued, however, quite the opposite preanalytic vision has guided American common-law property rules over much of the last two centuries. ${ }^{96}$ In describing what he terms the "antiwilderness bias" in American property law, Sprankling notes that a variety of commonlaw doctrines reflect the efforts of early American judges to "modif[y] English property law to encourage the agrarian development, and thus destruction, of privately owned American wilderness."97 These early courts transformed adverse possession, for instance, from a doctrine designed to protect the true owner of land against frivolous title claims to one designed to promote the effective exploitation of land.98 Judicial attention shifted from ensuring that the adverse possessor's activities signaled adequate notice of a title claim to assessing whether the possessor's activities constituted a reasonably productive use of the land in question. "By lowering the legal threshold for adverse possession [in this manner]," Sprankling writes, "courts tended to transfer title from idle owner $E$ to proven user $F$, whose development track record predicted future exploitation." 99 In other words, courts actively promoted the development of land.

A host of other property doctrines reflect this pro-development, "antiwilderness" bias, ${ }^{100}$ all seemingly premised on the assumption that the fabled abundance of the American frontier is limitless. Yet, as Sprankling writes, "[p]roperty rules crafted in an age of wilderness abundance are ill-suited to today's age of wilderness scarcity."101 Rather, contemporary common law principles should reflect the spaceman economy vision by requiring careful consideration of the diversity of land uses and their concomitant environmental impacts and importance. Moreover, as ecological economists have noted, undeveloped land should not be seen as necessarily idle given that the "wild" state of land can provide a variety of ecological services that are of benefit to humans and often cannot be replaced cost-effectively by industrial alternatives. ${ }^{102}$ A common-law property system that retains an "antiwilderness" bias may fail to appreciate the water filtration, soil stabilization, and other vital ecological services provided by undeveloped land.

Similarly, though some commentators have criticized conservation easements and other ecologically motivated servitudes on land as unduly restrictive of future generations, ${ }^{103}$ such legal instruments also may be

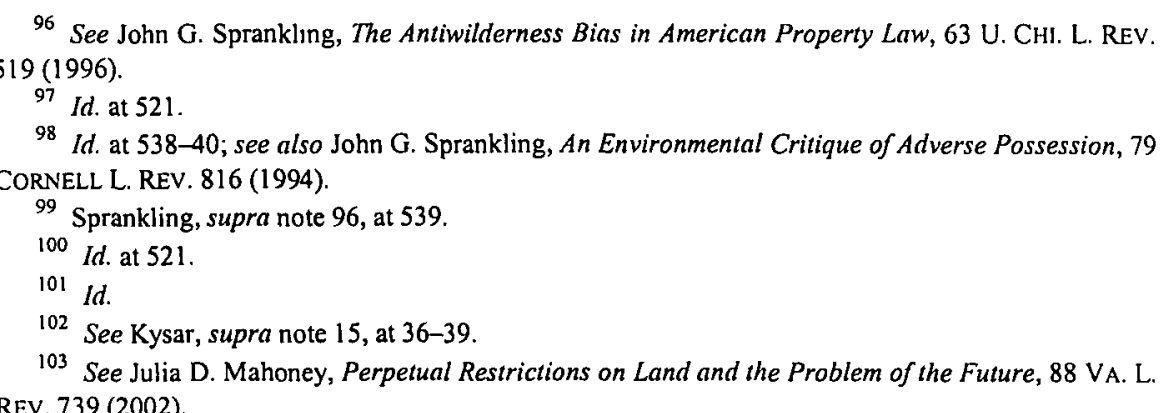


viewed as a practical response to the troublesome fact that present generations cannot not bind the land use decisions of future generations. Whether a parcel is subjected to a conservation restriction or transformed into a parking lot, the parcel in both cases will have been modified in ways that limit the uses to which future generations can put the land. The legal recognition of conservation servitudes, which has been accomplished through state statutes, ${ }^{104}$ simply represents a judgment that certain legal instruments should be available to allow current owners to accomplish intergenerational transfers of undeveloped, as well as developed, land. Again, such a judgment is not necessarily contrary to the fundamental principle of property law that favors "the maximization of the value of land." 05 Rather, as ecological economists have argued, often the most beneficial use of land is conservation, given that land left to the processes of natural transformation can provide multiple ecological services to humans. ${ }^{106}$ In other words, the dichotomy between "developed" and "preserved" land is not only unstable, ${ }^{107}$ it is false. Preserved land can be highly developed, if by "developed" one means a state beneficial to human well-being.

In short, judicial willingness to consider the lessons of ecological economics might lead to a more harmonized vision of property in which wilderness is not equated with idleness or preservation with stagnation. American property law developed in a vastly different era of land use from today, one in which the frontier wilderness was seen as unimaginably vast. The famous Lockean proviso that private ownership of resource use is collectively maximizing only so long as "there is enough, and as good left in common for others" 108 arguably has become an issue of actual, rather than merely philosophical, concern. Contemporary property law therefore should be premised on a vision of finitude, not plenitude.

2. Fugitive Property and the Optimal Exploitation of Resources.The standard law and economics account of natural gas, wild animals, and other resources that do not conform to fixed, definable boundaries serves as another example of how ecological economic insights might inform common-law decisionmaking. As Robert Cooter and Thomas Ulen explain, such "fugitive property" presents an efficiency tradeoff between overutilization costs and administrative costs. ${ }^{109}$ The "rule of first possession," in

104 See id. at 749-50.

105 Id. at 771 .

106 It is important to note that such "undeveloped" land does not imply a static state of nature. See DANIEl. B. BotKIn, Discordant HaRmonies: A NEW ECOlogy FOR THE TWENTY-FIRST CENTURY (1990) (critiquing a view of nature in which ecosystems exist in static equipoise); A. Dan Tarlock, The Nonequilibrium Paradigm in Ecology and the Partial Unraveling of Environmental Law, 27 LOY. L.A. L. REV. 1121 (1994) (assessing the implications of new, dynamic ecological paradigms for law and environmental management).

107 See Mahoney, supra note 103, at 763-67.

108 John LoCkE, SECond TREATISE of Civil Government ch. 5, § 27 (Peter Laslett ed., 1963).

109 ROBERT COOTER \& ThOMAS ULEN, LAW AND ECONOMICS 112-15 (2d ed. 1997). 
which property rights are given to the first user who reduces the resource to actual possession, provides legal certainty and administrative ease, but simultaneously encourages waste in the form of rapid exploitation of natural resources. An alternative rule, such as a "rule of tied ownership," in which resources belong to the owner of real property wherein the resources are found, helps to prevent the "race to exploit" caused by a rule of first possession. At the same time, however, the rule increases administrative costs by hinging ownership on facts that are difficult and expensive to discern and that may be subject to rapid change. Without knowing more about the relative distortions caused by the competing rules, it is impossible to say which rule best promotes economic efficiency. ${ }^{110}$

Ecological economic analysis of law would enrich this textbook law and economics account by demonstrating that only the rule of first possession creates undesirable scale effects, in addition to indeterminate efficiency effects. According to Cooter and Ulen, the rule of first possession promotes resource exploitation at faster than optimal rates because it grants entitlement holders a right not only to the productive value of the resource, but also to the premiums commanded by its scarcity value in the future. ${ }^{111}$ Thus, in an effort to capture future scarcity rents by claiming title to resources currently, firms engage in inefficient (essentially, premature) exploitation under the rule of first possession. ${ }^{112}$ In addition, however, they also confound efforts to maintain an optimal scale of resource use. From a social perspective, the decision to exploit a resource rests not only on whether the exploiting firm could have put its investment to some more beneficial current use, but also on whether the resource ought, as a matter of ethics and distributive justice, to remain available for exploitation by future generations. ${ }^{113}$ In other words, current exploitation may be both intragenerationally inefficient and intergenerationally unjust. The "race to exploit" caused by the rule of first possession undermines both social goals.

In short, although an efficiency analysis alone is indeterminate, the additional consideration of scale effects counsels against a rule of first possession in the context of fugitive property. The efficiency loss created by the higher administrative costs of tied ownership is not purely fungible with the negative effects of the rule of first possession, which include not just cur-

110 Id. at 114.
111 Id. at 113 .
112 Of course, in some circumstances, possession need not entail exploitation. For instance, one could pump oil from the ground in order to claim title under the rule of first possession, but not necessarily utilize the resource until a later date. In other settings, however, possession and exploitation tend to go hand in hand. With respect to the traditional "rule of prior appropriation" for water use, for instance, possession has been defined as exploitation. See Reed D. Benson, Maintaining the Status Quo: Protecting Established Waters Uses in the Pacific Northwest Despite the Rules of Prior Appropriation, 28 ENVTL. L. 881, 886 (1998) ("The traditional steps needed to establish a water right are intent, diversion of water from its natural source, and application of water to a beneficial use.").

113 See WEISS, supra note 67, at 1-15. 
rent allocative inefficiency but also distortions in the ethical distribution of scarce resources across time. Thus, whenever possession of a resource is tantamount to current exploitation of it, ${ }^{114}$ the rule of first possession will complicate attempts to limit the scale of resource use.

To be sure, an alternative such as the rule of tied ownership does not by itself guarantee that resources will be exploited in the manner deemed most appropriate vis-à-vis future generations. It does, however, eliminate the urgency to exploit resources now simply in order to establish one's claim of title. A more direct means of restricting premature consumption of a resource would require rethinking the very notion of common law property rights. For instance, an ecological economic approach to fugitive resources might counsel courts to recognize property rights only to the extent of a socially approved level of annual extraction of a resource, rather than the total stock of the resource. ${ }^{115}$ This approach would go beyond existing doctrines that restrict "waste" of a resource by directly limiting the level of permissible resource use, irrespective of whether it is to be put to productive use.

3. Property Rules, Liability Rules, and Nature's Cathedral.-As a final example of how ecological economics might inform common-law decisionmaking, consider the much-analyzed question of whether a plaintiff's entitlement to be free from nuisance activities by neighboring landowners should be protected by injunctive or monetary relief. ${ }^{116}$ The canonical law and economics view, first articulated by Guido Calabresi and Douglas Melamed, ${ }^{117}$ holds that damages remedies are preferable in situations where parties are unlikely to bargain, due to the presence of high transaction costs. For instance, when factory pollutants harm neighboring homeowners, problems of strategic behavior may prevent the parties from allocating legal entitlements through bargaining. ${ }^{18}$ In such a situation, judges should protect the homeowners' right to be free of harmful pollution by awarding monetary relief, despite the traditional availability of injunctions for ongoing nuisances. In this manner, the factory can decide for itself whether to "purchase" the homeowners' entitlement by paying an ex post damages award, effectively circumventing hold-out problems and other impediments to bargaining posed by the homeowner class.

Cooter and Ulen examine the related question of whether damages should be awarded on a temporary or permanent basis. ${ }^{119}$ These theorists

\footnotetext{
114 See COOTER \& ULEN, supra note 109 , at 113.

$115 C$. infra text accompanying notes $226-36$ (describing a legislatıve proposal along such lınes). I am indebted to Buzz Thompson for suggesting this point.

116 See Rachlinski \& Jourden, supra note 95, at 1546-50 (reviewing legal economic literature with regard to this issue).

117 See Guido Calabresı \& A. Douglas Melamed, Property Rules, Liability Rules, and Inalienability: One View of the Cathedral, 85 HARV. L. REV. 1089 (1972).

118 Id. at 1106-07.

119 See COOTER \& ULEN, supra note 109, at 141-42.
} 
note that a temporary damages award, compensating plaintiffs for past harm but requiring them to return to court to recover for harm caused in the future, is costly to administer but provides adequate incentives for defendants to adopt cost-efficient technological improvements to avoid future liability. ${ }^{120}$ Conversely, a permanent damages award, compensating plaintiffs for all past and future expected harm, is cheaper to administer but entails an efficiency loss because "permanent damages create no incentive for injurers to adopt technical improvements that reduce external costs below the level stipulated in the judgment."121

Again, however, an ecological economic analysis of the alternative rules helps to resolve the apparently indeterminate tradeoff between administrative and allocative efficiency. Notably, the permanent damages approach purports to compensate landowners for the value of both present and future harm to their land. Assuming that a satisfactory value can be placed on such harm, the defendant then can decide whether its environmentally destructive activities are more valuable than the external costs imposed on present and future neighbors. As Cooter and Ulen note, however, such a judgment requires the selection of a discount rate to reduce future damage to a present value. ${ }^{122}$ As discussed above, ${ }^{123}$ one cannot rely on a discount rate to determine logically the distribution of entitlements across generations. Specifically, one cannot reduce a future generation's environmental harm to a present value without first deciding whether to permit the future environmental harm to occur. The temporary damages approach avoids such conceptual problems by allowing for continual reassessment of the reasonableness of the defendant's activity. The temporary approach, therefore, is preferable to the permanent approach because it does not require courts to resolve in a final manner questions of intergenerational rights to environmental goods and services.

More fundamentally, an ecological economic perspective calls into question the insight of Calabresi and Melamed that courts should prefer damages remedies in cases of high transaction costs. From an efficiency perspective, such liability rules are preferable to property rules because they allow the circumvention of collective action problems, strategic behavior, and other well-known barriers to Coasean trading. ${ }^{124}$ The scale effects of liability rules, however, may not be as desirable as their efficiency effects. As just noted, a permanent damages rule confounds attempts to restrict polluting activities to environmentally sustainable parameters by attempting to subsume such judgments within the discount rate. Moreover, even a tempo-

\footnotetext{
120 Id. at 141

121 Id.

$122 \mathrm{Id}$.

123 See supra text accompanying notes 69-73.

124 See James E. Krier \& Stewart J. Schwab, Property Rules and Liability Rules: The Cathedral in Another Light, 70 N.Y.U. L. REV. 440, 451 (1995).
} 
rary damages liability rule depends critically on the availability of comprehensive scientific information regarding environmental harm and a satisfactory means of reducing that harm to a monetary judgment. ${ }^{125}$ In other words, courts must have substantial knowledge in order to set an appropriate level of damages.

In light of such informational demands, an argument in favor of property rules might be that, where one party's activities threaten a potentially irreplaceable natural resource, ${ }^{126}$ property rule protection affords the owner of that resource an ability to contest both the other party's and the court's valuation. In a sense, this approach merely transfers the informational demands from the polluter or the court to the resource owner. Indeed, ecological economists would contend that no individual polluter or resource owner possesses the scientific information and ethical authority necessary to determine whether the resource in question should be converted to present use. Rather, such judgments generally should be made as part of a comprehensive public scheme of the sort to be described in subpart B.

Nevertheless, in the context of prescribing background rules regarding environmentally harmful nuisances, an ecologically inclined court might prefer to award property-rule protection to the aggrieved neighbors precisely because such parties would then be in a position to refuse offers made by the polluting factory that did not equal or exceed their willingness-to-accept valuation of the environmental harm (which is likely to be higher than either their willingness-to-pay valuation or some ex post objective calculation).127 A default rule of property rule protection, in other words, provides a deliberately precautionary stance with respect to the destruction or impairment of potentially irreplaceable environmental goods and services. ${ }^{128}$

4. Summary.-As detailed in the next subpart, scholars have given far more systematic thought to the question of how ecological economic theory might shape legislative policymaking. Nevertheless, based on the preceding, largely speculative examples, ecological economics also appears to offer promising theoretical aid in the construction of common-law rules. Just as efficiency has become a meta-principle guiding the selection of legal

125 The argument in this section builds on the notion of "assessment costs" articulated by James Krier and Stewart Schwab in their enlightening extension of the Calabresi and Melamad framework. See id. at 453 ("Just as obstacles to bargaining (transaction costs) might impede efficient exchanges by the parties in property rule cases, so problems in obtaining and processing information (assessment costs) might impede efficient damage calculations by the judge in liability rule cases.").

126 To be sure, the Boomer case itself involved "dirt, smoke and vibration emanating from [a cement] plant" that seemingly would not cause irreversible harm to neighboring resources. Boomer v. Atl. Cement Co., 309 N.Y.S.2d 219 (1970). Application of the Boomer reasoning, however, need not be limited to such temporary, reversible environmental harms.

127 See Krier \& Schwab, supra note 124 , at 457-58.

128 Cf. DANiel A. FARBER, ECO-PRAGMATISM 113 n.36 (1999) (arguing for a presumption in favor of injunctive relief in Boomer settings as part of an "environmental baseline" for common law decısionmaking). 
rules in all manners of common-law contexts, the ecological economic concept of scale also could become a dominant consideration in legal decisionmaking. Indeed, because it relates to the ultimate capacity for human economic activity to sustain itself, scale arguably may be of even more importance than efficiency.

\section{B. The Public Policy Implications of Ecological Economics}

Many existing environmental statutes could be said to incorporate the type of conservationist approach advocated by ecological economists. For instance, as interpreted by the Supreme Court in TVA $v$. Hill, the Endangered Species Act ${ }^{129}$ represents "a plain intent of Congress . . . to halt and reverse the trend toward species extinction, whatever the cost."130 Similarly, the Ninth Circuit at one time interpreted the Delaney Clause ${ }^{131}$ to require the Environmental Protection Agency "to prohibit all [food] additives that are carcinogens, regardless of the degree of risk involved." 132 Other examples include the Clean Air Act, which adopted national ambient air quality standards without regard to cost, ${ }^{133}$ and the 1973 Clean Water Act, which announced a goal of eliminating all water pollution by $1985 . .^{134}$ Such statutes, and their judicial interpretations, may be seen as reflecting a concern that ecological values do not receive due consideration under a strict cost-benefit analysis. To combat such potential shortchanging, legislators seek to remove certain environmental goods from utilitarian balancing altogether.

Such an approach, however, is both more extreme and less comprehensive than the approach desired by ecological economists. By purporting to require conservation of water resources "whatever the cost" or eliminate carcinogens "regardless of the degree of risk involved," these pieces of legislation appear to banish instrumental and scientific judgment from the decisionmaking process altogether, to the dismay of ecological as well as conventional economists. Moreover, even in combination, the statutes men-

12916 U.S.C. $\S \S 1531-1544(2000)$

130 TVA v. Hill, 437 U.S. 153, 184 (1978).

131 The Delaney Clause provides that "no [food] additive shall be deemed to be safe if it is found to Induce cancer when ingested by man or animal, or if it is found, after tests which are appropriate for the evaluation of the safety of food additives, to induce cancer in man or animal." 21 U.S.C. $\$ 348$ (c)(3)(A) (2000). Because a literal reading of the provision would have required the Environmental Protection Agency to ban a number of commonly used agricultural chemicals, the Agency for years sought to avoid invoking the "Delaney Clause" through a variety of means. See Richard L. Revesz, Federalism and Environmental Regulation: A Public Choice Analysis, 115 HARV. L. REV. 553, 633 n.548 (2001). In 1996, Congress passed the Food Quality Protection Act, which effectively reduced the scope of the "Delaney Clause" by redefining the term "food additive" so that it does not include chemical pesticide residues See 21 U.S.C. $\$ 321(s)$ (1994 \& Supp. II 1996).

132 See Les v. Reilly, 968 F.2d 985, 986 (9th Cir. 1992).

133 See 42 U.S.C. $\S 7409$ (b) (2000); see also Whitman v. Am. Trucking Ass'ns, 531 U.S. 457 (2001).

${ }^{134}$ See 33 U.S.C. $\$ 1251(\mathrm{a})(1)(2000)$ (" $[\mathrm{I}] \mathrm{t}$ is the national goal that the discharge of pollutants into the navigable waters be eliminated by $1985 . ")$. 
tioned above fail to provide anything approaching the comprehensive monitoring and maintenance of scale that ecological economists believe is necessary to obtain optimal, long-run development. In their view, the "singlemedia, single-species, single-substance and single life cycle stages approaches," 135 typified by statutes like the Endangered Species Act, ultimately must yield to a more holistic set of policy tools if society's objective is to achieve the normative goal of sustainability or otherwise monitor its scale.

This subpart attempts to provide an overview of such policy tools. It does so by organizing ecological economic reform proposals under headings corresponding to significant determinants of society's ecological impact. As noted above, Daly has described population and per capita resource use as two key determinants of the level of throughput in the economy. ${ }^{136}$ A widely used variation on Daly's description disaggregates resource use into separate factors of per capita consumption levels and per unit of consumption environmental impact levels. Thus, the environmental impact of a society $(I)$ is equal to the product of its population $(P)$, its affluence or per capita level of consumption $(A)$, and its technology or environmental impact per unit of consumption (T): $I=P \times A \times T .^{137}$ This formulation makes explicit the role of technology in achieving sustainability: the greater efficiency with which society uses its natural resources, the greater level of affluence or population size it may reach while keeping environmental impact constant. The task of governmental decisionmakers, under an ecological economic approach, is to design policy tools in such a way that the determinants of scale exert a combined impact that suits society's collective judgment regarding the desirable level of its economic activity (e.g., within the carrying capacity of the environment).

1. Technology.-The ecological economic approach to improving technological efficiency is not controversial. It follows the long-accepted insight of Pigou that an ideal market must force the internalization of costs causally related to an economic activity. So long as a firm does not bear responsibility for these costs, and so long as victims face impediments to bargaining with the firm, ${ }^{138}$ the firm lacks strong incentives to avoid or minimize the costs. Pigou recognized that by levying a tax on the firm equal in amount to the "externality," governments can force the firm to behave in the manner that benefits society most-namely, by developing alternate production methods that avoid or reduce the externality or by passing on the cost of the externality to consumers so that they may better decide whether the consumption item is desirable in light of its full social price.

135 Charles W. Powers \& Marian R. Chertow, Industrial Ecology: Overcoming Policy Fragmentation, in THINkING ECologically 19, 23 (Marian R. Chertow \& Daniel C. Esty eds., 1997).

136 See supra text accompanying note 43.

137 See Kenneth N. Townsend, Steady-State Economies and the Command Economy, in VALUING THE EARTH: ECONOMICS, ECOLOGY, ETHICS, supra note 28, at 275, 290-91.

${ }^{138}$ See supra text accompanying note 62. 
As noted above, ${ }^{139}$ ecological economists believe that such Pigouvian taxes are insufficient by themselves to regulate society's environmental impact, primarily because the informational demands of such taxes outstrip scientific knowledge of ecosystem dynamics and ethical agreement on proper valuation methods for environmental goods and services. Nevertheless, these theorists still view environmental taxes as a welcome improvement over existing policies, which sometimes fail even to attempt regulation of environmental externalities. This subpart, therefore, reviews a series of concrete proposals to improve technological efficiency by forcing private cost functions to better correspond to social cost functions, recognizing that such policies can fulfill only a limited role within a comprehensive approach to regulating scale.

a. Subsidy Elimination.--The clearest case for reform can be made with respect to government subsidization of industries that harm the environment. ${ }^{140}$ Here, the government not only fails to tax industries for the costs of their external effects, but actually lowers internal industry cost functions by providing lucrative subsidies. As a result, the privileged industry conducts its business with a balance sheet tilted in favor of exploitative activities. Such government distortion of the market can produce extreme results, as in the case of the fishing industry:

The collapse of many of the world's fisheries would not have been possible without massive governmental subsidization of the fishing industry. In 1995, the fishing industry spent $\$ 124$ billion to catch $\$ 70$ billion worth of fish. Governments made up virtually all of the difference through direct subsidization of gear and infrastructure, low-interest loans, price supports, fuel-tax exemptions, and scores of other mechanisms designed to increase the income from catching fish. ${ }^{141}$

David Roodman has provided a useful taxonomy of the many ways in which the public subsidizes activity that harms the environment. ${ }^{142}$ The most obvious come in the guise of cash handouts, tax breaks, below-market interest or exchange rates, and other manipulations designed to provide capital to an industry that the unfettered market might be unwilling to sup-

139 See supra text accompanying notes 69-73. It also should be mentioned that Pigou himself felt that such regulatory taxes would be nearly impossible to operationalize: "[T] determining the right rates of bounty and of duty would be extraordinarily great. The data necessary for scientific decision are almost whole lacking." A.C. PIGOU, SOCIALISM VS. CAPITALISM 42-43 (1947).

140 See Robert N. Stavins, Market-Based Environmental Policies, in PUBLIC POLICIES FOR EnVIRonMental Protection 31, 55-56 (Paul R. Portney \& Robert N. Stavins eds., 2000).

141 Barton H. Thompson, Jr., People or Prairie Chickens: The Uncertain Search for Optimal B10diversity, 51 STAN. L. REV. 1127, 1166 (1999). Given that open-seas fisheries are a prototypical example of the commons problem, see supra note 37 , it is likely that certain fisheries would have collapsed even without "massive governmental subsidization." Nevertheless, subsidization surely exacerbates the problem.

142 See David Malin Roodman, The Natural. Wealth of Nations: HaRNessing the Market FOR THE ENVIRONMENT 31-44 (1998). 
port. The government's subsidization of the fishing industry typifies this approach. Other examples include agricultural price support payments, which amounted to $\$ 4.5$ billion in the United States in $1996,,^{143}$ and billions of dollars worth of direct subsidies to the coal industry in nations such as Germany, Japan, and Spain. ${ }^{144}$ Perhaps the most striking of this type of subsidy are the sizeable benefits that U.S. mining, oil, and gas companies receive through a series of congressionally granted tax dispensations. ${ }^{145} \mathrm{In}-$ deed, Congress's Joint Committee on Taxation estimates that the oil and gas industries in the United States are effectively exempt from income tax liability. ${ }^{146}$

Government giveaways and below-cost sales of publicly owned resources, such as minerals, precious metals, and timber comprise a second group of subsidies. In the United States, for example, the mining industry still operates under the General Mining Law of 1872, which allows private companies the right to mine on public land for between $\$ 2.50$ and $\$ 5.00$ per acre. ${ }^{147}$ As an example of how beneficial this statute can be to private entities, consider Barrick Goldstrike Mines, Inc., which in 1994 obtained rights to an estimated $\$ 10$ billion in resources on public land for a fee of $\$ 10,000{ }^{148}$ Similarly, the logging industry benefits from government spending on access roads and other management services that cost more than the value of U.S. Forest Service timber sales. ${ }^{149}$ In Alaska's Tongass National Forest, for instance, the government spent $\$ 389$ million between 1982 and 1988 on roads and other assistance to private logging operations, yet received only $\$ 32$ million in return. ${ }^{150}$

Roodman's final group of subsidies consists of government charges for the use of roads, sewers, irrigation systems, and other elements of infrastructure for less than their full cost of creation and operation. For instance, the agricultural sector obtains irrigation services from water reclamation projects through fifty-year, no-interest loans and other cost-reducing mechanisms. ${ }^{151}$ As a result, from 1902 to 1986 , the government spent be-

\footnotetext{
143 Id. at 67.

144 Id. at $72-73$.

145 See Mona L. Hymel, The Population Crisis: The Stork, the Plow, and the IRS, 77 N.C. L. REV. $13,117-23$ (1998).

${ }^{146}$ See id. at 122; see also Stavins, supra note 140, at 56 (noting that fossil fuel energy subsidies total some $\$ 17$ billion annually).

147 See General Mining Law of 1872, 30 U.S.C. $\$ \S 22-45$ (2000); Sam Kelan, An 1872 Mining Law for the New Millenium, 71 U. COLO. L. REV. 343, 348 (2000); GEORGE COGGINS ET AL., FEDERAL PUBLIC LAND AND RESOURCES LAW 95-96 (1993).

148 See Kelan, supra note 147, at 356-57.

149 See Thompson, Jr., supra note 141, at 1168 (noting that "[i]n the early 1990s, over half of the National Forests lost money on timber sales; annual forestry losses were approximately $\$ 300-\$ 400$ million per year").

150 See ROODMAN, supra note 142 , at 51 .

151 Thompson, Jr., supra note 141 , at 1167.
} 
tween $\$ 47$ billion and $\$ 99$ billion (in 1997 dollars) more than it earned on public irrigation projects. ${ }^{152}$ Likewise, the U.S. government loses an estimated $\$ 4.4$ billion annually by selling power below cost from its dams and nuclear reactors. ${ }^{153}$ Meanwhile, the government spends approximately $\$ 1$ billion a year on subsidized loans to extend power lines throughout rural regions, placing alternative energy sources such as solar panels and natural gas turbines at a competitive disadvantage in what might otherwise be favorable markets. ${ }^{154}$

From an economic perspective, the danger of such subsidization is twofold. First, it encourages private investment in resource exploitation that might otherwise be uneconomic. Second, it provides inaccurate price information to consumers by burying much of the cost of resourceintensive products within the general tax burden. ${ }^{155}$ Together, these effects promote arguably unsustainable levels of production and consumption throughout the economy. The ecological economic strategy to counter such an effect is both simple and obvious: eliminate the subsidies. The more challenging task, however, is to implement such a strategy in light of the impressive lobbying power of vested subsidy beneficiaries. ${ }^{156}$ One useful regulatory approach might be to withdraw subsidies in a gradual fashion, allowing for an adjustment period for the once-favored industry. Broader structural changes, such as campaign finance reform or amendment of the Administrative Procedure Act, also have been considered as ways to overcome political and legal obstacles to reform governmental resource disposition. ${ }^{157}$

Commentators justifiably bemoan the political difficulty of removing extensive and lucrative natural resource subsidies. Nevertheless, there is also danger in adopting a worldview in which all firms are seen as purely self-interested, all bureaucrats captured, and all politicians beholden. As David Spence has noted, the public choice model that gives rise to such cynicism lacks overwhelming empirical support. ${ }^{158}$ Firm behavior, it turns out, can be explained by a variety of factors other than pure rational maxi-

\footnotetext{
152 ROODMAN, supra note 142 , at 82 .

153 Id. at 81 .

154 Id. at 82 .

155 If demand for the product of a subsidized industry is relatively inelastic, consumers might purchase approximately the same amount of the product even when the subsidy is eliminated. In this manner, it might be a form of double-counting to discuss uneconomic investment and inaccurate price information as separate consequences of subsidization. However, even if subsidies do not increase aggregate demand, they still make benefited industries artificially profitable and forfeit a valuable potential source of government tax revenue.

156 See Thompson, Jr., supra note 141, at 1166, 1169.

157 See Harold J. Krent \& Nicholas S. Zeppos, Monitoring Governmental Disposition of Assets: Fashioning Regulatory Substitutes for Market Controls, 52 VAND. L. REV. 1705 (1999).

158 See David B. Spence, The Shadow of the Rational Polluter: Rethinking the Role of Rational Actor Models in Environmental Law, 89 CAL. L. REV. 917, 961-65 (2001).
} 
mization, while much of the history of environmental legislation and regulation belies the simplistic industry capture theory at the heart of environmentalist critiques of the political system. ${ }^{159}$ In Spence's view, abandoning hard-nosed pessimism about human nature may be the first step toward a broader, more unified process of environmental decisionmaking: "Just as incremental disillusionment with the rational polluter model grows one person at a time, so too may incremental exposure to the benefits of cooperation and collaboration produce a growing pro-reform constituency." 60 One day, perhaps, even the 1872 mining law will be amended.

b. Ecological Tax Reform.-While subsidy elimination aims to correct government intervention favoring environmentally harmful activities, a second policy tool, ecological tax reform, ${ }^{161}$ aims to correct government failure to intervene when activities externalize costs onto society and the environment. In both cases, the market cannot perform its allocative function efficiently because prices do not reflect the full social costs associated with production of a commodity or product. Ecological economists dispute the ability of market-corrective taxes alone to ensure environmental sustainability, ${ }^{162}$ yet they support such measures as part of a suite of policy tools designed to better manage the scale of the human economy. Indeed, in recent years, a consensus has emerged among ecological economists regarding the general features that such an ecological tax scheme should display. ${ }^{163}$

First, taxes should be levied upon various types of pollution, including "particulates, carbon dioxide, ozone precursors, and other noxious substances." 164 In the ideal Pigouvian sense, the tax should be set equal to the marginal environmental cost of production: the cost of common resources used in production in a way that causes uncompensated detriment to others. ${ }^{165}$ However, such an exercise presumes an unrealistic degree of scientific

\footnotetext{
159 Id. at $960-77$.

${ }^{160}$ Id. at 997; see also David B. Spence, Paradox Lost: Logic, Morality, and the Foundations of Environmental Law in the 21st Century, 20 CoLUM. J. ENVTL. L. 145 (1995).

161 See Steve Bernow et al., Ecological Tax Reform, BIOsCIENCE, Mar. 1, 1998, at 193.

162 See supra text accompanying notes 69-73.

163 Because the concept of using government taxing authority to achieve environmental policy goals has been widely analyzed in the legal academic literature, this section will only briefly summarize the viewpoint of ecological economists on the issue. See, e.g., Don Fulterton \& Gilbert E. Metcalf, Environmental Taxes and the Double-Dividend Hypothesis: Did You Really Expect Something for Nothing?, 73 CHI.-KENT. L. REV. 221 (1998); Joe Loper, Evaluating Existing State and Local Tax Codes From an "Environmental Tax" Perspective: The Case of Energy-Related Taxes, 12 PACE ENVTL. L. REV, 61 (1994); Adam Chase, The Efficiency Benefits of "Green Taxes": A Tribute to Senator John Heinz, 11 UCLA J. ENVTL. L. \& POL'Y 1 (1992); Amy C. Christian, Designing a Carbon Tax: The Introduction of the Carbon-Burned Tax (CBT), 10 UCLA J. ENVTL. L. \& POL'Y 221 (1992); Richard J. Pierce, Jr., The Constitutionality of State Environmental Taxes, 58 TUL. L. REV. 169 (1983).

164 Bernow et al., supra note 161, at 194.

165 See Richard A. Westin, Understanding Environmental Taxes, 46 TAX LAW. 327, 331-32 (1993).
} 
knowledge and popular agreement on environmental valuations. ${ }^{166}$ As a practical matter, therefore, the tax must be set according to some combination of scientific, economic, and political judgments. Despite this inevitable imprecision, ecological taxes arguably stand to achieve pollution reductions more cost-effectively than traditional environmental regulations due to their ability to encourage decentralized decisionmaking and innovation. Ecological taxes allow greater private flexibility in the determination of methods to achieve pollution reductions, a result almost uniformly lauded by economists. ${ }^{167}$

Second, the revenues generated by ecological taxes should be rebated to taxpayers through corresponding reductions in income and payroll taxes. ${ }^{168}$ Because pollution taxes would apply heavily to energy sector firms, and because low-income individuals tend to spend a disproportionately high portion of their income on energy, ${ }^{169}$ ecological tax reforms could potentially have a regressive effect on low-income taxpayers. This result can be avoided by pairing pollution taxes with reductions in income and payroll taxes, ${ }^{170}$ a strategy that would simultaneously help ensure the politically and economically desirable tax feature of "revenue neutrality."171

Third, the taxes should be phased in "gradually and predictably over a number of years to help ensure an orderly, low-cost transition."172 The ability of firms to anticipate future tax liabilities is crucial for maintaining macroeconomic stability, as well as for encouraging appropriate investment in resource-saving technologies. The gradual introduction of the taxes could coincide, roughly, with normal capital replacement cycles, thereby reducing the transitional cost of production changes. The government, with its interest in "maintain[ing] a reasonably stable and predictable stream of revenue from the new taxes," 173 also would benefit from a planned phase-in approach. A gradual introduction of ecological tax reform would allow the

166 See supra text accompanying notes 58-63.

167 See Nathaniel O. Keohane, Richard L. Revesz, \& Robert N. Stavins, The Choice of Regulatory Instruments in Environmental Policy, 22 HARV. ENVTL. L. REV. 313, 331-14 (1998) (noting "economists' consistent endorsement" of market based over command and control regulations). But see Daniel H. Cole \& Peter Z. Grossman, When Is Command-and-Control Efficient?, 1999 WIS. L. REV. 887 (arguing that command and control regulations may promote greater efficiency under certain plausible assumptions regarding informational uncertainty and administrative costs).

168 See Bemow et al., supra note 161 , at 194.

169 Id. at 195.

170 Id. In a related proposal, the authors suggest that "a small fraction of the tax revenue [should be used] to provide transitional assistance for communities, workers, and pollution-intensive industnes that are strongly affected by the tax." $J d$.

${ }^{171}$ A tax proposal is revenue neutral when it does not alter the aggregate amount of tax revenues collected and therefore also does not alter the macroeconomic position established by government fiscal policies.

172 Bernow et al., supra note 161 , at 195.

${ }^{173}$ Id. 
possibility for scheduled rate increases to maintain government revenues relatively constant despite a likely decline of polluting activities under the new incentive scheme. ${ }^{174}$

Finally, some steps could be taken to lessen the handicap that industries most affected by market-corrective taxes may face in international competition. If competing industries in other nations do not face equivalent ecological taxes, unrestricted import of goods from those nations would negatively impact domestic industry and might ultimately undermine the efficacy of ecological tax reforms by spurring capital flight to less-regulated jurisdictions. ${ }^{175}$ "To address this effect," Steve Bernow and colleagues write, "a compensatory import tariff could be levied on goods manufactured in countries with less stringent environmental policies." 176 Such a measure would ensure that, at least in the domestic market, firms paying a pollution tax are not competitively disadvantaged by imports from "countries with less stringent environmental policies." 177

The benefits of instituting ecological tax reforms may go beyond simply reducing the incidence of pollution. Other things being equal, any tax whether levied on labor, capital transfers, wealth inheritance, consumption, pollution, or resource exploitation tends to discourage performance of the taxed activity. ${ }^{178}$ Given this simple economic fact, ecological economists argue that taxes should be shifted away from socially desirable activities, such as employment, and onto socially harmful activities, such as pollution. As theorists and politicians have long recognized, ${ }^{179}$ taxes need not serve only the purpose of generating public revenue. Instead, taxes can increase resource efficiency and decrease pollution by correcting for externalities, while simultaneously improving employment prospects by lessening disincentives to buy and sell labor created by the income tax. ${ }^{180}$ As the ecological economists point out, "[s]uch "ecological' tax reform has the potential to ease both the burden of taxation on parts of the economy and the burden of the economy on the environ-

${ }^{174} I d$.

175 Id. It should be noted that the present empirical significance of such standards-lowering competition is unclear. See Daniel C. Esty, Bridging the Trade-Environment Divide, 15 J. ECON. PERSP. 113, 123-24 (2001).

176 Bernow et al., supra note 161 , at 195.

177 Id. A difficulty posed by such an import tariff, however, is that it would be subject to challenge as an impermissible restraint on trade. See infra text accompanying notes 196-219.

178 Specifically, the tax increases the cost of conducting the activity, making it less attractive relative to other untaxed activities. Cf. Christine Jolls, Behavioral Economics Analysis of Redistributive Legal Rules, 51 VAND. L. REV. 1653, 1655 (1998) (noting that "[h]igher taxes on the wealthy will tend to discourage people from earning high incomes").

179 See, e.g., Saul Levmore, Taxes as Ballots, 65 U. CHI. L. REV. 387, 387 (1998) ("We are familiar with two kinds of taxes: those that raise revenue and those that aim to induce behavior of one kind or another.").

180 See Bemow et al., supra note 161 , at 194. 
ment."181 Broader public recognition of this possibility over time may help to enhance the political feasibility of ecological economic tax reform.

c. Consumer Product Market Reform.-As with prices for basic material resources, environmental advocates have argued that retail prices for finished consumer goods fail to capture their full costs of production, transportation, and disposal, thereby permitting consumption to rise above socially optimal levels. In recent years this thesis has achieved international political salience. At the 1992 Earth Summit, 178 nations endorsed the view that contemporary consumer product markets are in need of serious reform, especially in industrialized nations such as the United States: "The major cause of the continued deterioration of the global environmental degradation is the unsustainable pattern of consumption and production, particularly in the industrialized countries, which is a matter of grave concern, aggravating poverty and imbalances." 182

Despite this international recognition, growth in consumption shows little sign of abatement. Population levels and gross world product per person have more than doubled since $1950 .{ }^{183}$ This growth has been accompanied by an expansion in the capture and use of raw natural resources. For example, production levels of coal, oil, natural gas, ${ }^{184}$ and timber ${ }^{185}$ grew by at least a factor of two since 1950. During the same five decades, per capita paper consumption expanded from twenty-five kilograms per person to

181 Id. at 193. The existence of this employment stimulating effect, known as the "double-dividend" in the literature, is subject to some debate. Don Fullerton and Gilbert Metcalf argue that the wage gain only occurs when existing command and control regulations already restrict pollution at or near the socially optimal level, such that the first dividend (improvement in environmental quality) is not attained through ecological tax reform. See Fullerton \& Metcalf, supra note 163, at 227-29. When command and control regulations are set at socially optimal levels of pollution, consumer product prices already reflect internalized pollution costs, such that a shift to environmental tax regulation would not raise production costs or otherwise reduce consumer purchasing power. By contrast, Fullerton and Metcalf argue that when environmental taxes are instituted in a cuirently under-regulated area of pollution (such that the first dividend can be attained), consumer product prices ultimately will rise to offset the wage gain caused by the tax shift. Id. Because of this price rise, the real net wage of employees may remain constant despite the reduction in income and payroll taxes (such that the second dividend cannot be attained).

This analysis, however, appears to treat the demand for labor as constant regardless of whether env1ronmental taxes are instituted; that is, it appears to assume that reducing the cost of labor relative to capital by shifting the tax burden will not increase the demand for labor. To the extent that labor and capital are substitutes, a tax shift may stimulate employment, ultimately raising the real net wage despite the price-rise effect noted by Fullerton and Metcalf. That is, while the wage gain caused by cutting taxes may be offset by higher prices, the wage gain caused by increased demand for labor may not

182 Report of the United Nations Conference on Environment and Development vol, I, at 37, 38, U.N. Doc. A/Conf.151.26 (1992). The phrase "unsustainable pattern of consumption" fails to capture fully the ecological consequences of current consumer product markets. As explained above, in addition to population levels, environmental degradation is a consequence of both a society's pattern of consumption (technology) and its level of consumption (affluence).

183 See LESTER R. BROWN et al., ViTAL SIGNS: 1999, at 64-65, 98-99 (1999).

184 See id. at 48-49.

${ }^{185}$ See id. at 76-77. 
fifty-one. ${ }^{186}$ The transportation industry experienced similar growth. In 1998, automotive manufacturers produced thirty-eight million automobiles, raising the global fleet to 508 million, up from only fifty-three million in 1950.187 Over the last fifty years, the number of people per automobile dropped by almost eighty percent. ${ }^{188}$ Air travel, the most polluting form of transportation per kilometer traveled, grew almost one hundred-fold over the same period and now accounts for five percent of annual world oil consumption. ${ }^{189}$ Similar expansion occurred in per capita copper, steel, meat, cement, plastic, and aluminum consumption. ${ }^{190}$ In the aggregate, global consumption achieved a level that is almost historically inconceivable: "Measured in constant dollars, the world's people have consumed as many goods and services since 1950 as all previous generations put together."191

Many commentators agree, therefore, that legal rules should ensure that consumer product prices reflect total product costs, thereby allowing consumers to appreciate the full impact of their market choices. ${ }^{192}$ The fact that total cost entails the internalization of a number of distinct types of product externalities may require an array of diverse legal instruments. For instance, a products liability regime of enterprise liability would go a long way toward enhancing the physical safety of consumer products by internalizing the costs of product-caused personal injuries. ${ }^{193}$ Similarly, the environmental taxes described in the previous subpart would accomplish the internalization of a great deal of pollutant externalities associated with resource-intensive products. James Salzman analyzes a third type of policy instrument, "extended producer responsibility," that would require manufacturers to retake possession of consumer goods upon the expiration of their useful lives. ${ }^{194}$ Such regulations would complement these other tools by encouraging manufacturers to design and market products that are not only less dangerous and less resource-intensive, but also less generative of product packaging and other forms of incidental waste.

A consumer products-regulatory scheme incorporating these and other cost-internalizing instruments might greatly enhance the efficiency of product markets by providing incentives for market actors to reduce costs that previously they had ignored. When environmental and personal injury costs are forced onto the balance sheets of consumer product manufacturers,

186 Id. at $78-79$.

187 Id. at $82-83$.

188 Id.

189 Id. at 86-87.

190 ALAN THEIN DURNING, How MUCH IS ENOUGH? 29 (1992).

191 Id. at 38.

192 See, e.g., James Salzman, Sustainable Consumption and the Law, 27 ENVTL. L. 1243, 1257

(1997); Jon D. Hanson \& Douglas A. Kysar, Taking Behavioralism Seriously: Some Evidence of Market Manipulation, 112 HARV. L. REV. 1420, 1553-65 (1999).

193 See Hanson \& Kysar, supra note 192, at 1553-71.

194 See Salzman, supra note 192, at 1270-77. 
those firms would undergo a dynamic change in product design and marketing strategy toward more sustainable practices. ${ }^{195}$ Likewise, consumers would be better informed of the real consequences of their consumption choices, resulting in a demand shift toward those products that are least costly in the full meaning of the term. In the aggregate, manufacturer and consumer incentives would combine to greatly increase the efficiency with which society derives utility from its use of resources.

d. International Trade Regulation.-During the second half of the twentieth century, a massive expansion in international trade and global economic activity occurred. In constant dollars, gross world product expanded six-fold, from $\$ 6.4$ trillion in 1950 to $\$ 39.3$ trillion in $1998 .{ }^{196}$ Over the same period, world trade exports as a share of gross world product more than doubled to fourteen percent. ${ }^{197}$ The number of corporations operating in more than one country rose from 7,000 in 1970 to 53,607 in 1998, with those corporations now controlling at least 448,917 foreign subsidiaries. ${ }^{198}$ Concurrently, the indebtedness of developing nations rose from $\$ 277$ billion in 1971 to $\$ 2.2$ trillion in $1997 .{ }^{199}$

A crucial legal catalyst to the development of this global economy has been the operation of trade agreements among nations, most notably the Global Agreement on Tariffs and Trade (GATT) and its successor institution, the World Trade Organization (WTO). ${ }^{200}$ Designed to liberalize trade by prohibiting discriminatory government action against foreign producers, the agreements typically prohibit quantitative trade restrictions such as import quotas, limit the use of tariffs, and subject remaining nontariff trade restrictions to certain rules of international law. Under GATT, for instance, member nations cannot treat products originating in, or destined for, foreign members differently from either similar domestic products or similar products from different foreign GATT members. ${ }^{201}$ These superimposed principles of international economic dealing apply to all domestic regulation, regardless of whether the regulation is directly concerned with international trade. ${ }^{202}$

195 Even with the playing field tilted by externalities, several contemporary business firms are discovernng that ecologically sustainable practices can be quite profitable. See Amory B. Lovins et al., A Road Map for Natural Capitalism, HARV. BUS. REV., May-June 1999, at 145 (reviewing several illustrative firms). In a market characterized by cost-internalization, firms would be forced to adopt such innovative practices.

196 BROWN ET AL., supra note 183, at 65.

197 Id. at 69.

198 Id. at 136.

199 Id. at 66-67.

200 See Richard B. Stewart, Environmental Regulation and International Competitiveness, 102 YALE L.J. 2039, 2041-42 (1993).

201 General Agreement on Tariffs and Trade, Oct. 30, 1947, art. 1, 61 Stat. A-11, 55 U.N.T.S. 194, 198 [hereinafter GATT].

${ }^{202}$ Most trade agreements provide explicit exceptions for certain categories of regulation. For instance, GATT allows nations to restrict import of goods produced in another country by prison labor. GATT, supra note 201, at 61 Stat. A-11, 55 U.N.T.S. at 262. 
While their contribution to the rise of the global economy is undisputed, free trade agreements have more recently come under fire from environmentalists for their apparent subversion of domestic environmental policies. In a series of rulings, GATT and WTO panels struck down U.S. regulations facially intended to serve environmental purposes as unduly restrictive of trade. ${ }^{203}$ The most widely discussed of these rulings concerned a U.S. prohibition on imports of tuna harvested by techniques, such as drift net harvesting, that result in large numbers of incidental deaths to dolphins. ${ }^{204}$ Because the U.S. regulation purported to restrict imported tuna according to the method by which the tuna had been harvested, a GATT panel determined that the legislation was not "primarily aimed at the conservation of dolphins,"205 but rather was intended to confer an unfair trade advantage on the U.S. fishing industry or, at a minimum, to force extraterritorial application of U.S. environmental regulations. ${ }^{206}$ The panel declined to apply Article XX(g) of GATT, which provides an exception for trade restrictions "relating to the conservation of exhaustible natural resources," or to apply Article XX(b), which provides an exception for restrictions "necessary to protect human, animal or plant life or health," 207 reasoning that other, less restrictive measures were available to the United States to pursue its conservationist goals.

The dolphin-tuna ruling rested on the fifty-year-old language and vision of GATT which reflects, on a global scale, the "cowboy economy" concept identified by Boulding. Indeed, an explicit goal of GATT, as expressed in its Preamble, is to "[promote] a large and steadily growing volume of real income and effective demand, develop[] the full use of the resources of the world and expand[] the production and exchange of goods." 208 These aspirations reflect various aspects of growth economics that ecological economists have challenged: namely, the belief that natural resources can be put to "full use" by humans without destroying the biophysical integrity of the earth; the belief that "steadily growing" demand can be attained without causing population and consumption levels to exceed sustainable or even desirable limits; and the belief that production can be "expand[ed]" infinitely without concern for depleting natural resource inputs or overtaxing the absorptive capacities of ecosystems with pollution outputs. Even Article XX of GATT, which acknowledges the need to ex-

\footnotetext{
203 See Padideh Ala'i, Free Trade or Sustainable Development? An Analysis of the WTO Appellate Body's Shift to a More Balanced Approach to Trade Liberalization, 14 AM. U. INT'L L. REV. 1129, $1137-69$ (1999) (reviewing rulings).

204 See United States-Restrictions on Imports of Tuna, Sept. 3, 1991, GATT B I.S.D. 39S/155

205 See id. at para. 5.33.

206 See id,; see also Dispute Settlement Panel Report on United States Restrictions on Imports of Tuna, June 1994, 33 I.L.M. 839, 897 (ruling on related aspects of the Marine Mammal Protection Act and noting that under GATT nations cannot "[f]orce other countries to change their policies within their own jurisdictions").

207 GATT, supra note 201, at 61 Stat. A-11, 55 U.N.T.S. at 262

208 GATT, supra note 201, at Stat. A-11, 55 U.N.T.S. at 194.
} 
empt environmental protection efforts from trade liberalization obligations, ${ }^{209}$ treats the conflict between economic and ecological goals as a narrow one requiring only a simple carve-out for environmental legislation, as if the two goals generally exist in separate, unrelated spheres. In other words, GATT overlooks the more fundamental relationship between economic activity and ecosystem functioning.

With the institution of the WTO, however, the international community has shifted its view toward the conception of a spaceman economy. The Preamble to the WTO proclaims the body's commitment to the "optimal use of the world's resources in accordance with the objective of sustainable development, seeking both to protect and preserve the environment and to enhance the means for doing so." 210 In addition, the WTO established in 1994 a Committee on Trade and Environment, which makes recommendations regarding "the need for rules to enhance the positive interaction between trade and environment measures, for the promotion of sustainable development." 211 These institutional changes soon began to inform decisions by the Appellate Panel of the WTO in its review of foreign-nation challenges to domestic environmental legislation. ${ }^{212}$ For instance, in reviewing a U.S. ban on shrimp imports from countries that did not implement certain sea turtle conservation measures, the Appellate Panel took pains to point out that it "had not decided that the protection and preservation of the environment is of no significance to the Members of the WTO." 213 Many international trade and development scholars have interpreted the ruling as a sign of growing recognition within the WTO of the importance of harmonizing economic and ecological activity. ${ }^{214}$

If society's goal is to achieve sustainability, or otherwise regulate its scale, the WTO's recognition of the interrelationship between economic activity and the environment should be encouraged. Many of the regulatory proposals examined in this Article may have dampening effects on global trade by requiring the internalization of costs that previously have been externalized. For instance, extended producer responsibility, which requires manufacturers of consumer products to accept return of products and packaging upon expiration of their useful lives, could be characterized as a restraint on trade that favors domestic producers. Foreign producers from nations lacking comparable laws may not have access to the durable materials and efficient technologies that flourish under extended-producer respon-

209 See supra text accompanying note 207.

210 Agreement Establishing the World Trade Organization, Apr. 15, 1994, 33 I.L.M. 1144, 1144.

211 GATT Ministerial Declaration on Trade and Environment, Apr. 14, 1994, 33 I.L.M. 1267, 1268 (1994).

212 See Ala'i, supra note 203, at 1154-69.

213 Report of the Appellate Body on United States-Import Prohibitions of Certain Shrimp and Shrimp Products, Oct. 12, 1998, WTO Doc. No. WT/DS58/AB/R, at para. 185.

214 See, e.g., Ala'i, supra note 203, at 1169. 
sibility laws and may therefore be placed at a competitive disadvantage visà-vis domestic producers. ${ }^{215}$ Similarly, in the case of ecological tax reform, governments may need to impose tariffs on imports from nations that do not impose comparable environmental regulations in order to discourage producers from fleeing to "pollution havens." 16 Like extended producer responsibility laws, these tariffs may be subject to challenge under existing principles of international trade.

For this reason, the exceptions contained in Article XX of GATT for regulations "relating to the conservation of exhaustible natural resources," or "necessary to protect human, animal or plant life or health" 217 should be reaffirmed by the WTO member nations in a manner that removes doubt concerning the international legality of ecological economic reforms. As Daly argues, such a reaffirmation would be perfectly consistent with the economic logic of free trade. The purpose of trade liberalization agreements, from an economic perspective, is to prevent unfair government support of domestic industries or "the protection of an inefficient domestic industry from competition with more efficient foreign firms." 218 The purpose of ecological economic reforms, including import tariffs that equalize domestic and foreign goods under such reforms, is to "protect[] an efficient national policy of cost internalization against standards-lowering competition from countries that, for whatever reason, do not count all environmental and social costs." 219 Thus, both free trade agreements and ecological economic reforms aim to achieve efficiency by prohibiting certain market failures caused by the government. The former prohibits market distortions caused by government interference while the latter targets government failure to interfere. In either case, the goal is to attain allocative efficiency through accurate pricing.

2. Affluence.-As one can see, a significant number of policy recommendations aim to influence society's ecological impact by enhancing the technological efficiency with which society consumes resources. Scholars have completed far less work in relation to the issues of affluence and population, the remaining determinants of society's ecological impact. There are at least two important reasons for this disparity. First, the task of designing policy instruments to remedy market failures and encourage technological advancements is a familiar one. Most of the tools described in the previous section are variations on principles that long have been known to economists and policymakers. Second, the task of restricting percapita consumption and population levels raises deeply moral issues about

\footnotetext{
215 Cf. Salzman, supra note 192, at 1283-85 (noting that "added costs and inferior bargaining power" may pose a de facto trade barrier to foreign producers).

216 See supra text accompanying note 177.

217 See GATT, supra note 201, at 61 Stat. A-11, 55 U.N.T.S. at 262.

218 DALY, supra note 43, at 147.

219 Id.
} 
which economics has been largely agnostic. To the extent that growtheconomic concepts currently dominate policymaking discussions, therefore, lawmakers and the public have not recognized an urgent need to implement programs relating to consumption and population levels.

Ecological economists argue, however, that technological advances in resource efficiency alone cannot limit ecological impact when both consumption and population levels are rising. As Gro Harlem Brundtland, former Prime Minister of Norway, stated:

It is simply impossible for the world as a whole to sustain a Western level of consumption for all. In fact, if seven billion people were to consume as much energy and resources as we do in the West today we would need ten worlds, not one to satisfy all our needs. 220

Despite impressive improvements in resource productivity over the last few decades, growth in both consumption and population levels has caused society's overall use of resources to outpace efficiency advances: "From 1970 to 1990 , average energy intensity fell in OECD countries by $20 \%$, yet total energy consumption grew by $25 \%$ and greenhouse emissions grew by $15 \%$."221 In short, the implication of the $I=P \times A \times T$ equation is that, unless science is about to fashion a technological substitute for the earth itself, consumption and population levels must be controlled in order to limit ecological impact.

a. Natural Resource Depletion Quotas.-With respect to consumption levels, the policy instruments described above are insufficient by themselves to restrict the volume of resource use that occurs within a society. While improvements in the information-providing and costinternalizing functions of the market can vastly improve the quality of market decisionmaking, only more stringent controls can directly affect the total quantity of consumption that society undertakes. Put differently, in light of the practical difficulty of identifying and pricing environmental externalities and the logical impossibility of using discounting as a means of intergenerational resource distribution, ${ }^{222}$ Pigouvian taxes alone cannot resolve the problem of scale. Instead, in order to achieve an ecologically sustainable level of consumption, society must turn to mechanisms outside of the traditional economic policy spectrum.

The first such mechanism developed by ecological economists addresses the need to set an absolute limit to the amount of natural resources that an economy consumes in a given time period. In addition to the creation of certain environmental externalities that can be addressed through

\footnotetext{
220 Salzman, supra note 192, at 1245-46 (quoting Brundtland).

221 Id. at 1268 n.1 14 (quoting NICK ROBINS \& SARAH ROBERTS, RETHINKING PAPER CONSUMPTION 8 (Norwegian Ministry of Environment, Commissioned by OECD Work Program on Sustainable Production and Consumption, 1996)).

222 See supra text accompanying notes 60-77.
} 
ecological tax reform, ${ }^{223}$ extraction and consumption of natural resources poses an internal analytical problem due to the nonrenewable or exhaustible characteristic of many of those resources. When a fossil fuel or other nonrenewable resource is exploited, it is treated as current income under national accounting principles such as GDP, even though it actually represents a depletion of nonrenewable natural capital. ${ }^{224}$ In nonaccounting parlance, society treats extraction of the resource as regularly reproducible activity, rather than conversion of an irreplaceable share of humanity's one-time endowment of natural wealth. This misconception is what prompted Georgescu-Roegen to warn that current use of steel, petroleum, and other nonrenewable resources necessarily forecloses their use by future generations. ${ }^{225}$

Daly proposes instituting a system of depletion quotas that would assist both in reconceptualizing the role of natural resources in human activity and in providing a concrete policy tool for ensuring long-term sustainable exploitation of renewable and nonrenewable energy sources. The general rule under such a system would be "to deplete nonrenewables at a rate equal to the rate of development of renewable substitutes." 226 The government would set aggregate nonrenewable production levels "so that the resulting price of the nonrenewable resource is at least as high as the price of its nearest renewable substitute."227 By linking nonrenewable resource use with the generation of viable renewable substitutes, Daly's depletion quota would make sustainability a direct aim of production rather than merely a hoped-for side effect. For nonrenewables that lack viable substitutes, the level of production would be set by regulators in a manner that reflects a fundamentally ethical judgment regarding the relative value of consumption by present versus future generations. Renewable resources also would be subject to a depletion quota system, but would be somewhat easier to quantify: "For renewables, the quota should be set at an amount equivalent to some reasonable calculation of maximum sustainable yield." 228

Once these levels have been determined, the government would auction off the appropriate number of depletion quota rights to intermediate buyers who could then sell the rights to producers in a competitive resource

\footnotetext{
223 See supra text accompanying notes 161-81.

224 Similarly, when an exhaustible resource is harvested at unsustainable levels, the proceeds represent in part a conversion of capital stock, not income.

${ }^{225}$ See Georgescu-Roegen, supra note 34, at 85 ("The upshot is clear. Every tıme we produce a Cadillac, we irrevocably destroy an amount of low entropy that could otherwise be used for producing a plow or a spade. In other words, every time we produce a Cadillac, we do it at the cost of decreasing the number of human lives in the future.").

226 DALY, supra note 43, at 82.

227 Herman E. Daly, The Steady-State Economy: Toward a Political Economy of Biophysical Equilibrium and Moral Growth, in VALUING THE EARTH, supra note 28, at 325, 344.

228 Id.
} 
market, thereby causing little or no allocative distortion in the resource aftermarket. ${ }^{229}$ Such a system simultaneously would represent a partial realization of the ideal tax on land rent proposed by economist Henry George. ${ }^{230}$ Unlike the current practice of free or below-market resource giveaways by the government, ${ }^{231}$ a depletion quota would capture unearned scarcity rent through public auction, allowing such revenue to be used for the national benefit rather than private enrichment. ${ }^{232}$ The system also might further enhance the efficiency with which society uses natural resources by providing incentives for the development of resource-saving technologies and efficient manufacturing processes, and by helping to spur the creation of commodities markets for recycled materials. ${ }^{233}$

Daly's proposed substantive rules explicitly adopt sustainability as the optimal scale of human economic activity. However, recognition of the concept of scale does not require one to accept automatically the norm of sustainability. ${ }^{234}$ For instance, one might argue that Daly's rule with respect to nonrenewables is too stringent because it essentially makes market actors indifferent between nonrenewables and renewable substitutes. In other words, bearing in mind the impact of present consumption on resource availability for future generations, one nevertheless might believe that humanity's finite endowment of nonrenewables should be utilized at some positive rate greater than the rate of renewable substitutes' development. The important point is that a political debate between proponents of Daly's strong sustainability and proponents of some less stringent level of control would represent precisely the type of democratic discussion that society should be having and that, as noted at the outset, ${ }^{235}$ it currently is not having with respect to its environmental policymaking. By recognizing the need to monitor absolute levels of resource consumption and by devising a policy instrument that requires legislative judgment about such levels, the ecological economic approach brings such vital issues to the fore. ${ }^{236}$

229 See Daly, supra note 227 , at 348.

230 See HENRY GEORGE, PROGRESS AND POVERTY (4th ed. 1904).

23. See supra text accompanying notes 141-54.

232 See Daly, supra note 227, at 343. An advisable use of part of the increased public revenue would be to provide wealth transfers to lower income people to help offset the regressive effect of higher resource prices. See supra text accompanying note 169.

233 See Daly, supra note 227 , at 343.

234 See supra text accompanying note 43.

235 See supra text accompanying notes 7-13.

236 It should also be emphasized that, whatever one's substantive judgment of the optimal scale of economic activity, a policy device such as the depletion quota system is still necessary to give effect to that judgment. Similarly, whatever one's view of the optimal amount of redistribution society should make to redress inequality, some mechanism such as the tax-and-transfer system is necessary to achieve the selected level of redistribution. 
In sum, the advantage that Daly's system adds to the use of ecological tax reform is a more direct means of regulating scale in recognition of society's limited ability to quantify and incorporate diffuse market externalities into resource taxes. While ecological tax reform appears promising as a tool to internalize some tangible costs of market side effects, such as pollution, Daly's quota system seems necessary to constrain the more direct consequences of market activity, such as depletion. Put differently, ecological taxes discourage the use of natural resources for ends less beneficial than the full social cost of resource consumption, thereby achieving allocative efficiency. They are limited in their effect, however, by the incompleteness of scientific knowledge regarding the extent and effect of environmental externalities, by the lack of consensus regarding ethically appropriate mechanisms for valuing environmental goods and services, and by the inability of discount rates to serve as a proxy for questions of intergenerational resource distribution. Depletion quotas circumvent these conceptual flaws by directly restricting aggregate resource consumption to levels reflecting both a social judgment regarding the distribution of resources between present and future generations and a degree of caution regarding humanity's ability to predict and measure the ecological consequences of economic activity. Depletion quotas thereby assist society in maintaining a desirable scale of resource use.

Neither ecological taxes nor depletion quotas are sufficient, by themselves, to achieve an economy that is optimal in both its efficiency and its scale. In other words, market-corrective policies must influence both technology and affluence in order to regulate the supply side of the human macroeconomy.

b. Limits to Competitive Consumption.-A second set of policy proposals that might aid in constraining consumption levels focuses on the demand side of the macroeconomy. These policies emerge from work by Richard McAdams on the phenomenon of relative preferences-which are those preferences that are defined in relation to the attributes or possessions of other individuals. ${ }^{237}$ McAdams examines the way in which such preferences can lead to socially wasteful, competitive consumption. ${ }^{238}$ For instance, if both $A$ and $B$ desire to own the largest sport-utility vehicle on the block, their mutually exclusive preferences can lead to a consumption "arms race," in which each makes a steadily greater investment in behemoth SUVs that cancels the effect of the other's investment. Similarly, if both $A$ and $B$ desire to send their child to the best college in the country,

237 Richard H. McAdams, Relative Preferences, 102 YALE L.J. 1 (1992). For other discussions of such interdependent preferences, see ROBERT H. FRANK, CHOOSING THE RJGHT POND (1985); FRED HiRSCH, SOCIAL Limits to GrowTH (1976); Robert A. Pollak, Interdependent Preferences, 66 AM. ECON. REV. 309 (1976).

238 McAdams, supra note 237, at 5. 
they might make increasingly greater and earlier investments in their child's pre-college education. ${ }^{239}$

Such investments become wasteful when they divert resources away from the satisfaction of other, nonrelative preferences. ${ }^{240}$ For instance, consider a case in which $A$ and $B$ are two coworkers, each vying for a promotion and each facing a choice between purchasing an ordinary pair of work pants and a pair that are made "wrinkle-free," through the application of formaldehyde in a process that is potentially harmful to textile workers. ${ }^{241}$ Both would prefer to purchase pants that do not carry a risk of harm to workers, absent concerns about appearances. Their need to be perceived as wearing neatly pressed attire, however, sets up a Prisoner's Dilemma in which both $A$ and $B$ will choose the potentially toxic pants in order to avoid lower appearance status in the competition for a promotion. The dilemma lies in the fact that the degree of wrinkling of one's clothing is a relatively observable attribute, while the harm caused to workers in their production is not. As a result, the utility gained from purchasing non-wrinkle-free pants does not contribute to one's relative appearance status. Some form of collective agreement, therefore, is necessary to constrain $A$ and $B$ from purchasing wrinkle-free pants when both might prefer the state of the world in which wrinkled, nontoxic pants prevail.

McAdams identifies three ways in which governments may help restrict the incidence of such competitive consumption. First, governments may tax the consumption of relative goods as a means of raising revenue to satisfy other nonrelative social needs. ${ }^{242}$ This approach is advantageous because it can lower the consumption volume of certain status goods with minimal macroeconomic distortion. For example, if the government levied an excise tax on diamonds, people might simply buy smaller diamonds that were equal in price to those that they would have purchased prior to the $\operatorname{tax}^{243}$ Second, governments may mandate the consumption of non-relative goods that might otherwise be sacrificed in favor of wasteful competitive consumption. ${ }^{244}$ Minimal standards for automobile safety represent a good

239 See Jonathan Kaufman, Grade Inflation: Suburban Parents Shun Many Public Schools, Even the Good Ones, WALL ST. J., Mar. 1, 1996, at A1 (describing costly and escalating efforts by parents to confer academic distinction on their children). As McAdams notes, these individual "arms races" are simply components of the consumer's effort to obtain an overall mix of positional goods that signifies success; consumers "purchase a combination of status goods in order to 'produce' a single commodity of overall social distinction or prestige." McAdams, supra note 237, at 70 (quoting George J. Stigler \& Gary S. Becker, De Gustibus Non Est Disputandum, 67 AM. ECON. REv. 76, 84, 88 (1977).

240 See McAdams, supra note 237, at 55-56.

241 See 29 C.F.R. $\$ 1910.1048$ (1996) (providing Occupational Safety and Health Administration standards for occupational exposure to formaldehyde); OSHA, STANDARD INTERPRETATION AND COMPLIANCE LETTERS: FORMALDEHYDE STANDARD CLARIFICATION (1989) (noting possibility of higher formaldehyde concentrations in wrinkle-free fabrics).

242 See McAdams, supra note 237 , at 72-76.

243 See id. at 75

244 Id. at $76-79$. 
example of this type of regulation, as do rules requiring minimum consumption levels of "health insurance, pensions, vacation time, and workplace democracy."245 Finally, governments may enact policies designed to foster social norms against competitive consumption. ${ }^{246}$ For instance, attaching civil liability to SUV owners for the nonreciprocal risk posed by their vehicles to other drivers ${ }^{247}$ might serve to express social disapproval of such vehicles.

The benefit of these policies from an ecological economic perspective lies in the fact that luxury goods often exact a significant environmental toll. The diminutive nature of precious metals and stones, for instance, scarcely suggests the ecological cost that is required to produce them. Extraction of metal ore for two gold wedding rings produces six tons of waste at mining sites. ${ }^{248}$ Similarly, 110 tons of such "overburden" earths are excavated to produce just one ton of copper ${ }^{249}$ Once the ore is separated from overburden, it is doused with potentially harmful chemicals, including cyanide, mercury, and sulfuric acid, producing a resultant waste known as "tailings." 250 Given the nature of this process, any policy that would reduce the size of jewelry necessary to achieve a given level of social status may be desirable not only due to its public revenue generation, but also due to its reduction in the sheer volume of global mining activities.

Other goods and services that on a global scale would be considered luxury items produce similar environmentally destructive consequences. Air travel requires forty percent more fuel than automobiles on a per-passenger, per-kilometer basis. ${ }^{251}$ Each kilogram of red meat requires three thousand liters of water, the equivalent of two liters of gasoline in petrochemicals and other farm inputs, and five kilograms of corn and meal that otherwise could be used to feed humans. ${ }^{252}$ The fickle fashion industry which, according to the U.S. Office of Technology Assessment, changed high-fashion trends nearly five times a year during the 1980 s, often prompts the disposal of clothing years before the end of its useful life. ${ }^{253}$ Such increased textile production carries a heavy environmental cost, including the use of pesticides and water for cotton farming, chemicals for synthetic fabric production, intense grazing

245 Id. at 77.

246 See id. at $79-83$.

247 See Gregory L. White, Car/Truck Crash Emphasis Should Be Side-Impact Protection, Producers Say, WALL ST. J., May 26, 1998, at B5 ("Government and auto-company statistics have shown that people in cars that are struck by light trucks and SUVs are far more likely to be seriously injured or killed than if they were hit by cars.").

248 GARY GARDNER \& PAYAl SAMPAT, Forging a Sustainable Materials Economy, in STATE OF THE WORLD 1999, at 41, 47 (Lester R. Brown et al. eds., 1999).
${ }^{249}$ Id.
250 Id.
251 See id.
252 See id. at 68.
253 See id. at 95. 
for wool and leather, and hazardous industrial dyes for coloration. ${ }^{254}$

Despite the heavy burden luxury-goods consumption seems to place on the environment, such consumption may in fact provide only fleeting enjoyment to its practitioners. Seeking satisfaction that many argue may be derived more reliably from nonmaterial sources such as social companionship, physical health, and mental stimulation, ${ }^{255}$ the competitive consumer continually trades in goods for the latest model with the latest features. The consumer desires simply to possess something that relatively few others are capable of attaining, an observable symbol that signifies success under prevailing social norms. By adopting policies designed to restrict the "arms race" of competitive consumption, governments not only could help reduce the incidence of environmental destruction that frequently attends such consumption, but could also steer consumers toward an emphasis on what many believe are stronger determinants of psychological welfare.

c. Limits to Total Consumption.-Policies addressing natural resource exploitation and competitive consumption nevertheless may be insufficient to form the entire basis of an ecological economic approach to per capita material consumption levels. Because these policies do not address the problem of regulating consumption by all members of society for all material resources, their use may not necessarily keep total ecological impact within an environmentally acceptable range. In such an event, Daly would require society to confront the philosophical task of defining and limiting its members to "a level of per capita wealth sufficient for a good life" that remains consistent with the ecological needs of the earth. ${ }^{256}$ Daly would thus ask society to utilize the regulatory power of the state to set per capita material throughput limits at a level within the best scientific estimate of ecological carrying capacities - an admittedly radical concept in the context of an economic tradition that believes the good of society is best served by exalting the right of individual market actors to collect and consume as they see fit.

To be precise, the total impact that a society exerts on its ecological base should be the focus of the limitation. Daly implicitly assumes that people would opt for an egalitarian distribution of such an impact quota. A society could just as easily, however, regulate aggregate rather than individual impact. It could, for instance, create a large-scale, zero-sum game by directly capping aggregate impact while allowing unregulated allocation of individual impact "rights." The resulting competition could lead to disparities in distribution, much like the current U.S. economy. Unlike the current economy, however, the system would be designed so that aggregate impact

\footnotetext{
254 See id. at 96.

255 See Douglas A. Kysar, Kids \& Cul-de-Sacs: Census 2000 and the Reproduction of Consumer Culture, 87 CORNELL L. REV. 853, 895-98 (2002) (reviewing sources).

256 See DALY, supra note 43, at 14.
} 
levels, taking account of the existing population size and the level of technological efficiency, remain within ecological constraints.

3. Population.-From the perspective of the cowboy economy, production is limited by labor rather than natural resources. Any increase in population size therefore can be seen as a desirable addition to the labor supply. However, the perspective of the spaceman economy reveals an inverse relationship between population growth and permissible levels of affluence. ${ }^{257} \mathrm{~A}$ smaller population can maintain higher consumption levels than a larger one, keeping ecological impact constant. Because total ecological impact must be limited in the spaceman economy, any policy that fosters reproductive growth therefore can be seen as one that restricts individuals to a lower standard of consumption. Given such a relationship, policymakers must examine means by which societies may both ethically and effectively regulate population sizes. In recent years, legal scholars have begun doing just that. ${ }^{258}$

a. Domestic Population Policy.-As a threshold matter, it is important to dispel the popular notion that overpopulation is a matter of concern only to developing nations. Because both population size and percapita resource intensity affects ecological impact, the United States turns out to be the most "overpopulated" nation on earth. ${ }^{259}$ At the request of the Earth Council in preparation for the Rio+5 Forum, scientist Mathis Wackernagel used an innovative measure known as the "ecological footprint" to estimate the ecological impact of the world's nations. ${ }^{260}$ This measure calculates the area of biologically productive land and water necessary to produce the resources consumed and to assimilate the wastes generated by a given population at a specified material standard of living. Recent data on ecological footprint analysis shows that Americans lead the most resourceintensive lifestyles on earth, requiring 10.3 hectares of biologically productive space per person. ${ }^{261}$ In light of the fact that the average Indian only utilizes 0.5 hectares, the total ecological footprint of India, the most populous nation on earth, is less than one-third the size of the U.S. footprint. ${ }^{262}$

257 See supra text accompanying note 137.

258 For instance, two provocative symposia recently have been devoted to the topic. See Paula Abrams, From Malthus to the Millennium: Population Law and Policy, 27 ENVTL. L. 1091 (1997) (introducing symposium); Timothy E. Wirth, Population-Challenges and Alternatives, $6 \mathrm{COLO}$. J. INT'L ENVTL. L. \& POL'Y 245 (1995) (same).

259 See Paul R. Ehrlich \& Anne H. Ehrlich, The Population Explosion: Why We Should Care and What We Should Do About It, 27 ENVTL. L. 1187, 1190-91 (1997).

260 MATHIS WACKERNAGEL ET AL., ECOLOGICAL FOOTPRINTS OF NATIONS: HOW MUCH NATURE DO THEY USE? HOW MUCH NATURE DO THEY HAVE? (1997). Wackernagel's collaborator Willam Rees had suggested the concept of "ecological footprints" as early as 1992 . See Willam E Rees, Ecological Footprints and Appropriated Carrying Capacity, 4 ENV'T \& URBANIZATION 121 (1992).

261 Redefining Progress, Updated Ranking List (1997), available at http:/www.rprogress.org/ resources/nip/ef/ef_nations_table.html.

262 Id. (calculating total footprint of India at $7,761,840$ square kilometers and the U.S. at $27,623,467$ square kilometers) 
Indeed, the total U.S. footprint is nearly twice as large as that of China, the next largest consumer of the Earth's ecologically productive area. ${ }^{263}$ These figures demonstrate that, unless Americans dramatically alter their consumption habits, population control is an issue of both international and domestic relevance.

On the domestic front, Mona Hymel has argued that U.S. tax policy should be reformed to eliminate its arguably pronatalist bias. ${ }^{264}$ The dependency exemption, head-of-household filing status, earned income tax credit, and child care credit policies all operate to lower the cost of reproduction, thereby raising incentives to have children at the margin. ${ }^{265}$ In contrast, Hymel advocates the institution of policies that would promote factors highly correlated with reduced fertility rates. Tax subsidization of public education and family planning programs, for instance, arguably could help to increase female educational levels and access to birth control technologies, both of which help to lower fertility rates. ${ }^{266}$ More directly, tax-preferred savings plans and other forms of incentives and penalties could be redesigned so that they are expressly contingent on family size. ${ }^{267}$ Hymel recognizes that such tax reform would influence population levels only indirectly; nevertheless, she believes that the effect would be significant enough to merit a serious reassessment of the role that tax policy plays in the growth of the U.S. population. ${ }^{268}$

b. International Population Policy.-Far more direct confrontation of population levels seems necessary in developing nations, where fertility rates are as many as four children above the rate necessary to keep population levels constant. ${ }^{269}$ Traditionally, policymakers have supported two divergent approaches to population regulation in developing nations. First, some policymakers have argued that "development is the best contraceptive" 270 because economic growth theoretically will reduce the demand

263 See id. (calculating China's total footprint at 14,967,780 square kilometers). To put the figures in perspective, consider the following statistic based on oil equivalent commercial energy use: "[T]he average African couple would have to have more than ninety children to equal the environmental impact from commercial energy use of a corresponding American couple with two chıldren." Judith $E$ Jacobsen, Population, Consumption, and Environmental Degradation: Problems and Solutions, 6 COLO. J. INT'L ENVTL. L. \& POL'Y 255, 270 (1995).

264 Hymel, supra note 145.

265 See id. at 55-68.

266 Id. at $68-73$

267 Id. at $72-75$.

268 Id. at 132.

269 See Ehrlich \& Ehrlich, supra note 259, at 1198. In recent years, signs of a trend toward declıning birth rates have emerged even among many developing nations. See Diana D.M. Babor, Population Growth and Reproductive Rights in International Human Rights Law, 14 CONN. J. INT'L L. 83, 86-87 (1999). Nevertheless, the dynamics of population growth indicate that humans will continue to rise in numbers for generations after such a decline. See id. at 87.

${ }^{270}$ Paula Abrams, Population Control and Sustainability: It's the Same Old Song But with a Different Meaning, 27 ENVTL. L. 1111 (1997) (describing motto of 1974 Bucharest World Population Conference). 
for children by shifting society from an agrarian to an urban-industrial center. Second, others have argued in favor of family planning programs, because access to birth control technologies and education will act as a "supply side" solution to the problem of overpopulation by providing a safe means of reducing pregnancy rates. ${ }^{271}$ Neither of these approaches has proven an unqualified success. Family planning efforts too often have been associated with the coercive programs conducted by nations such as China, India, ${ }^{272}$ Brazil, and Indonesia, ${ }^{273}$ while economic development has proven insufficiently correlated with reduced fertility to provide the "magic bullet" that demographers and economists hoped it would be. ${ }^{274}$ An additional problem with the economic development approach is that it often has meant, in practice, resource-intensive industrialization. In other words, stabilization of population arrives only at the cost of increases in per capita ecological impact, with an uncertain net effect.

In more recent years, social development theorists have championed a promising third approach that offers a refined analysis of the interplay between development and fertility. ${ }^{275}$ These theorists reject the view that economic development invariably reduces birth rates. Instead, they attempt to unravel the specific factors associated with development that lead to reduced fertility rates, so that policymakers can target those factors in particular. Under their analysis, two key determinants of low fertility rates are the educational level of women and their ability to participate in society outside of the home. ${ }^{276}$ More generally, "social development theorists argue that the critical factors in the reduction of fertility rates are increases in the status, education, and economic power of women." 277

By the 1994 World Population Conference in Cairo, social development theorists offered a "significant body of research demonstrating that birth rates are dramatically affected by social, rather than economic, development."278 In response, 160 nations adopted the Cairo Programme of Action, which links reproductive health to basic human rights and which requires nations "to make long-term investments in education, health care, and social policy that ultimately will affect the motivational factors relating to high fertility rates." 279 This new approach to population control improves

\footnotetext{
271 Id. at 1118.

${ }^{272}$ Robert M. Hardaway, Environmental Malthusianism: Integrating Population and Environmental Policy, 27 ENVTL. L. 1209, 1235 (1997).

273 See Ehrlich \& Ehrlich, supra note 259, at 1197.

274 Id. at 1199.

275 Id.; see also Amartya Sen, Fertility and Coercion, 63 U. CHI. L. REv. 1035, 1048 (1996).

276 Ehrlich \& Ehrlich, supra note 259, at 1199.

277 Abrams, supra note 270, at 1118.

278 Id. at 1124.

279 Id. (quoting Report of the International Conference on Population and Development, U.N. Dept. of Economic and Social Information and Policy Analysis, U.N. Doc. A/CONF.171/13 (1994)), available at gopher:/gopher.undp.org:70/00/ungopherspopin/icpd/conference/offeng/poa.txt.
} 
earlier efforts by international and domestic agencies because it expressly condemns fertility-related human rights violations while sharpening the focus of policies that seek to foster development among third-world nations.

This refinement should come as welcome news to environmentalists, who have traditionally remained silent on the issue of overpopulation given its link to divisive questions of reproductive rights and its historical association with coercive programs of bodily intrusion. ${ }^{280}$ Nevertheless, environmentalists and human rights advocates in some sense have been engaged in parallel struggles: environmentalists seek to overturn a vision of humanity as the unchecked dominator of nature, while human rights activists seek to overturn a similar vision of governments as the rightful dominators of women. ${ }^{281}$ Through the insights of social development theorists, these parallel aims form a joint goal of stabilizing populations by achieving greater gender equity. Indeed, the consensus reached at Cairo shows that " $[t]$ he most effective solution to the population problem also happens to be the most ethical."282

\section{Summary}

Beginning with the simple proposition that natural systems are limited in their ability to generate resources and absorb wastes, ecological economics unfolds into a panoply of heretofore unrecognized or underappreciated legal and public policy goals. As this Part demonstrates, the tools to achieve these goals are beginning to take shape in a variety of different academic literatures. Scholars have proposed several market-corrective actions that society can take to internalize, at least approximately, the environmental costs of economic activity, such as the elimination of natural resource-extraction subsidies, the shifting of the tax burden from socially desirable activities to ecologically harmful ones, and the reformation of consumer product markets by internalizing tangible product costs. The regulation of trade between nations also has been examined through the lens of ecological economics, suggesting ways to harmonize current global market policies with domestic environmental regulations.

The question of how to regulate population and consumption levels has received less attention in the literature. To this point, the main contribution made by ecological economists has been to highlight the fact that population and consumption levels are legitimate subjects of collective attention. Ecological economists promote this awareness by disaggregating the determinants of environmental impact into factors of technology, population, and consumption. While economic incentives to increase technological efficiency are theoretically familiar, policies designed to constrain absolute levels of consumption and population are both unfamiliar and controversial.

\footnotetext{
280 See Hardaway, supra note 272, at 1228.

281 See Abrams, supra note 270, at 1133.

282 Id. at 1134.
} 
As a result, scholars have spoken only generally about the need to limit the volume of resource extraction and competitive consumption. With respect to population levels, policies that increase educational and social opportunities for women appear to represent the most promising alternative for lowering reproduction rates.

The sweep of ecological economics within legal analysis is potentially broad. The laws and policies of tax, trade, consumers, products liability, and the environment all represent known areas of potential application of ecological economic insights; many others remain to be discovered. If the consensus of the world's scientific community turns out to be correct-namely, that "grave threats imperil the future of humanity and the global environment"283 - then the use of ecological economic concepts within legal analysis will only become more fruitful and more urgent as time passes.

\section{CONCLUSION}

The distinction between ecological and conventional economics is startlingly simple: ecological economists view the human economy as a subsystem of the environment, while conventional economists view the environment as a subsystem of the economy. The former vision emphasizes natural constraints on the expansion of human production, including both the scarcity of resource inputs to the economic process and the scarcity of pollution sinks to absorb waste outputs of the process. The latter vision admits of no such limits on human economic growth, given that no conceptual superstructure, such as the environment, exists "around" the economy to constrain it. Economic growth is limited only by the availability of human-made capital and labor, not by natural resources.

This elementary shift in preanalytic vision leads to surprisingly dramatic changes in policy recommendations. As leading ecological economist Herman Daly puts it, "[w]hen we draw a containing boundary of the environment around the economy, we move from 'empty-world' economics to 'full world' economics. Economic logic stays the same, but the perceived pattern of scarcity changes radically and policies must be changed radically."284 Particularly, the goal of market regulation becomes more complicated than merely seeking to maximize allocative efficiency. In addition to establishing market conditions that allow resources to be devoted to their most valued use, governments also must moderate the absolute scale of the human macroeconomy in light of the carrying capacity of the relevant ecosystem.

\footnotetext{
${ }^{283}$ Union of Concerned Scientists, World Scientists' Call for Action at the Kyoto Climate Summıt (1997) (statement of 1586 scientists from sixty-three countries, including 104 of the 178 living Nobel Prize winners in the sciences).

${ }^{284}$ DALY, supra note 16 , at 50.
} 
This Article has argued that the ecological economists' notion of scale not only demonstrates what is missing from some economic approaches to environmental problems, but also helps to explain why a national discussion regarding different visions of the environmental future did not accompany the 1990 Clean Air Act Amendments. ${ }^{285}$ Within a worldview that fails to recognize ultimate repercussions to environmental pollution, one might justifiably question why Congress should pay any attention whatsoever to the level of sulfur dioxide emissions permitted under the national trading scheme. If one assumes a limitless ability of nature to absorb waste outputs, then the determination of aggregate emissions limits for any particular environmental trading program becomes a judgment of little urgency.

Until the nation adopts a language that avoids both the absolute prohibitivism of 1970s-era ethical environmentalism and the absolute permissivism of the most bullish forms of growth economics, it will continue to struggle in its efforts to mount a democratic discussion regarding environmental quality. As this Article has argued, ecological economics provides the necessary language. Just as efficiency has become a meta-principle informing all areas of law and regulation, so too can the ecological economist's conception of scale. Indeed, if the ecological economists are correct in their assessment that scale is a vital, though neglected, concept in economics, then efficiency analysis by itself is nothing more than a one-bladed scissors. An economy that puts an ever-increasing strain on its natural environment may still allocate productive resources efficiently, but in doing so it simply will be making the best of an increasingly desperate situation.

285 See supra text accompanying notes 7-13. 
NORTHWESTERN UNIVERSITY LA W REVIEW 